\title{
The Quality of Fiscal Adjustment and the Long-Run Growth Impact of Fiscal Policy in Brazil ${ }^{1}$
}

\author{
Fernando Blanco \\ Santiago Herrera
}

\begin{abstract}
This paper describes the main trends of Brazil's fiscal policy during the last decade and analyzes: (1) the ability to raise the primary surplus in response to external shocks, (2) the pro-cyclical nature of fiscal policy, and (3) the long-run impact of government expenditure composition and taxation.

The use of the primary balance as a policy tool is analyzed within the Drudi-Prati model, wherein the government uses the primary balance to reveal its commitment to service its debt. We verify that both the debt ratio and the primary balance are determinants of spreads and credit ratings in Brazil. However, the relationship is non-linear: the impact of the primary balance on spreads is amplified as the debt ratio increases.

Using an Autoregressive Distributed Lag (ARDL) approach, we analyze the relationship between the primary balance and economic activity, finding a positive correlation in the long run. However, in the short run, fiscal expansions are associated with primary balance reductions and vice-versa during output contractions confirming the procyclical nature of fiscal policy in the short run.

The paper uses two approaches, ARDL and a cointegrating VAR, to analyze the interaction between public expenditure composition and taxation on growth. Similar results are obtained: large elasticities of output with respect to capital stocks, a significant negative impact of taxation on long-run GDP, and a negative impact of increasing government consumption and transfer payments on GDP. These results shed light on the contribution of fiscal policy to disappointing growth performance in Brazil during the past decade.
\end{abstract}

World Bank Policy Research Working Paper 4004, September 2006

The Policy Research Working Paper Series disseminates the findings of work in progress to encourage the exchange of ideas about development issues. An objective of the series is to get the findings out quickly, even if the presentations are less than fully polished. The papers carry the names of the authors and should be cited accordingly. The findings, interpretations, and conclusions expressed in this paper are entirely those of the authors. They do not necessarily represent the view of the World Bank, its Executive Directors, or the countries they represent. Policy Research Working Papers are available online at http://econ.worldbank.org.

\footnotetext{
1 The authors thank Gaobo Pang for helpful research assistance and Ethan Weisman for useful comments and suggestions. This paper is a rejoinder of several technical background papers by the authors for the Brazil Country Economic Memorandum (Report 25278-BR). A version of this paper was presented at the EcoMod Policy Modeling Conference in Paris, June 2004. Corresponding author: sherrera@worldbank.org
} 


\section{Introduction}

Throughout the 1990s, Brazil started a process of economic reform including liberalizing trade, relaxing price controls, and privatizing public enterprises. Although some problems remained at first, such as higher public sector deficits and limited exchange rate flexibility, the country corrected most of these and steered a course toward stability by the end of the millennium. In fact, since 1999, Brazil has made substantial efforts to adjust its fiscal accounts. The country has moved in the direction of credible rules that govern the outcome of the budget process and procedures that contribute to providing incentives and constraints to promote fiscal discipline and increase transparency. The hallmarks of these measures include the Fiscal Responsibility Law and the impressive primary surplus targets achieved between 1999 and 2005.

Despite the impressive results some vulnerabilities still remain. In particular, the quality of the fiscal adjustment brings doubts about growth prospects and the own continuity of the hard fiscal stance. The fiscal adjustment has been accomplished through strong revenue increases (the tax burden has grown from 29 percent of GDP in 1998 to 35 percent in 2004) and by curtailing public investment (investments by federal government fell from 1.1 percent of GDP in 1998 to 0.5 percent in 2005). The increase of the tax burden and the compression of public investment are harming growth prospects which can complicate future debt dynamics. On the other hand, the permanent increase of current expenditures and the impossibility to maintain the tax burden growth are negatively affecting the sustainability of the current fiscal adjustment effort. To sustain growth while re-orienting public finance towards investment therefore represents the next chapter of Brazil's national economic reforms.

The paper is organized in four sections following this introduction. The first describes the main fiscal trends since the 1990s, focusing mostly on the period 19992005. The second section focuses on a mechanism that would allow fiscal policy to be more responsive to shocks, by permitting automatic stabilizers to operate throughout the business cycle to mitigate the pro-cyclicality of Brazilian fiscal accounts. This section computes the long-run effects of different variables on the primary balance and estimates the cyclical component of the primary surplus. The third section examines the long-term impact of public finance on growth, using a modified production function approach, in which private and public capital are considered inputs, jointly with different types of public expenditure. Results indicate large elasticities of output with respect to capital stocks, negative impact of public consumption and transfers in the long run, and a significant negative impact of taxation on long-run GDP. The fourth section summarizes the results and concludes. 


\section{Background: Brazilian Fiscal Policy during 1990-2005}

This section is divided into four parts. The first one describes fiscal outcomes during the last 15 years, focusing on the fiscal adjustment of 1999-2005. The second section highlights the flexibility of fiscal policy during this volatile period, and examines the role of the primary surplus as a signaling device in a world of imperfect information. The third section assesses the quality of the fiscal adjustment identifying the type of adjustment carried out-revenue increasing or expenditure cutting. The fourth section attributes the type of fiscal adjustment to the high budget rigidity.

\section{A. Fiscal Policy Trends in Brazil}

During the last years of the military regime, the Brazilian public sector showed signs of financial fragility. Slower growth combined with the external shocks, led to a fall in public sector savings. The re-democratization process deepened the fiscal disequilibria, because the new democratic government set out to satisfy repressed social demands for redistribution. The 1988 Constitution expanded the social responsibilities of the state, guaranteed free access to social services, established higher social security benefits, and defined a generous regime for public sector employees (Bevilaqua and Werneck, 1998). The new Constitution also modified the federal fiscal system, creating an imbalance between resources and responsibilities among levels of government. Finally, the 1988 Constitution increased the rigidity of public spending through the earmarking of an important part of fiscal revenues.

These measures had a very perverse effect on public finances, but inflation postponed the collapse of the fiscal regime. During this high-inflation period, the asymmetric indexation to inflation of revenues and expenditures, higher for revenues than for expenditures, produced artificially positive balances (Cardoso, 1998). Additionally, the negative real interest rates and the inflation tax generated soft budget constraints and positive fiscal outcomes.

The evolution of fiscal accounts during 1990-2005 can be divided into three subperiods, as shown in Figure 1. The first one, 1990-1994, registers positive primary outcomes and operational equilibriums. In the second one, from 1995 to 1998, the primary surplus vanishes, while the last sub-period, 1999-2003, corresponds to the fiscal adjustment years and shows a permanent improvement of the primary surplus from $-0.2 \%$ of GDP in 1998, to 4.7\% in 2005. 


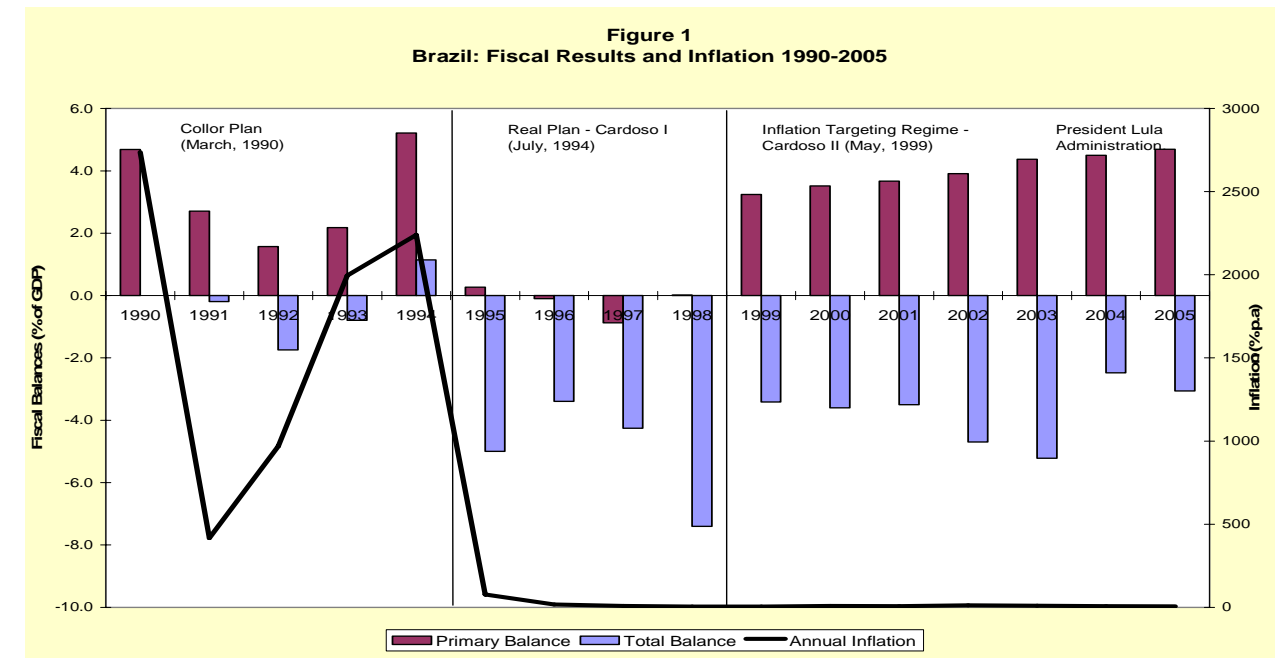

The end of the inflationary process in the mid 1990s coincided with deteriorating fiscal outcomes in 1995-98. Inflation was not only a revenue source, but was also a useful mechanism to control government spending in real terms during the high inflation era (Cardoso, 1998). This loss of flexibility, combined with a lack of decisive fiscal reform, produced rising public sector deficits. The excess spending relative to national income was financed in liquid international capital markets, with public debt rising from $29 \%$ of GDP in 1994 to almost 42\% in 1998.

The central bank sterilized these capital inflows through open market operations to avoid monetary expansion and maintain a pegged exchange rate. This response complicated the situation even more because it entailed rising central bank (domestic) debt and climbing interest rates that raised the cost of servicing public debt. High interest rates combined with the pegged exchange rate attracted even more capital, worsening the state of affairs. The higher debt and the rigid fiscal, monetary, and exchange rate policies, left the economy vulnerable and with no capacity to absorb shocks. When the Asian and Russian financial crises occurred in 1997-1998, Brazil was severely affected due to its sizeable external financing requirements. In January 1999, the central bank abandoned its crawling peg exchange rate regime in favor of a flexible rate and adopted an inflation-targeting framework for managing monetary policy.

In 1999, the country tackled its fiscal imbalance by launching the Fiscal Stability Program, which consisted not only in raising taxes, but also in designing a legal framework for fiscal policy management. The government set and met stringent targets for the primary fiscal surplus; the public sector primary surplus increased permanently from 3.3 percent of GDP in 1999 to 4.7 percent of GDP in 2005.

However, the high interest rates and the exchange rate devaluations of 1999, 2001 and 2002 prevented a more accentuated reduction of operational deficits. Consequently, the primary surpluses were not sufficient to truncate the rising path of public debt. Table 1 compares the three periods. During 1995-98, the operational balance deteriorated by almost 5\% of GDP in comparison with the period 1990-94. This was a result of a rise of $1.5 \%$ of GDP in interest payments and a fall of the primary surplus of $3.5 \%$ of GDP. The federal government was responsible for $60 \%$ of fall in the operational balance, and for 
more than $40 \%$ in the decrease of the primary surplus. States and local governments and public enterprises were responsible for $30 \%$ each for the worsening of the results.

Due mostly to the 2002 debt crisis (analyzed in the next section) and to tight monetary policy, interest payments rose from $4.8 \%$ of GDP in the $1995-98$ period to 5.5 percent of GDP in 1999-2005. The operational balance improved by 3.5\% of GDP, from $-5 \%$ of GDP to $-1.5 \%$ of GDP corresponding to an improvement of $4.2 \%$ of GDP in the primary balance. The Federal government contributed half the adjustment, while state and local governments and public enterprises with $25 \%$ of the adjustment in primary accounts $^{2}$.

Table 1: Fiscal Balances*, 1990-2005

\begin{tabular}{|c|c|c|c|}
\hline & \multicolumn{3}{|c|}{ Annual Averages (\% of GDP) } \\
\hline & $\begin{array}{c}1990-1994 \\
\text { (A) }\end{array}$ & $\begin{array}{c}1995-1998 \\
(B)\end{array}$ & $\begin{array}{c}1999-2005 \\
(C) \\
\end{array}$ \\
\hline $\begin{array}{l}\text { I Operational Balance (III - } \\
\text { II) }\end{array}$ & -0.05 & -5.01 & -1.46 \\
\hline Federal Government & 0.52 & -2.48 & -1.72 \\
\hline States and Municipalities & -0.25 & -1.98 & -0.30 \\
\hline Public Enterprises & -0.31 & -0.55 & 0.54 \\
\hline II Real Interest Payments & 3.33 & 4.84 & 5.48 \\
\hline Federal Government & 1.26 & 2.78 & 4.13 \\
\hline States and Municipalities & 0.86 & 1.64 & 1.08 \\
\hline Public Enterprises & 1.20 & 0.42 & 0.24 \\
\hline III Primary Balance & 3.27 & -0.17 & 4.01 \\
\hline Federal Government & 1.78 & 0.30 & 2.41 \\
\hline States and Municipalities & 0.61 & -0.34 & 0.78 \\
\hline Public Enterprises & 0.89 & -0.13 & 0.82 \\
\hline
\end{tabular}

* ( + ) Surplus ( - ) Deficit

\section{B. The Flexible Primary Surplus as a Device to Signal Fiscal Sustainability}

How do governments that are not fully credible signal regime sustainability? Based on the Drudi-Prati (2000) $)^{3}$ model that rationalizes debt accumulation and delayed stabilization, we analyze the Brazilian case. The main testable implication of the DrudiPrati (DP) model is the existence of a positive relationship between the spreads and the

\footnotetext{
${ }^{2}$ Regarding the operational balance, the federal contribution was low (only 16\%) due to the impact of the greater effect of interest rates on federal accounts. On the other hand, the interest payments for state and municipalities have been reduced because of the bail-out operation of 1997-98. This operation has substituted state bonds for federal bonds and re-scheduled state debt, producing a subsidy from the federal government to the states. This means higher interest payments for the federal government and lower ones for state governments.

${ }^{3}$ Drudi, F. and A. Prati. (2000). "Signaling fiscal regime sustainability,” European Economic Review, Vol. 44 pp. $1897-1930$.
} 
debt level and a negative association between spreads and primary balances. This relationship is conditioned on the debt level: Given uncertainty about the likelihood of default, the government will use the primary balance as a signaling tool to reveal to investors its true type. As the debt level rises, the dependable government (though not fully credible) will use more actively its primary balance as a signaling tool.

Spreads on sovereign debt are crucial determinants of the nominal exchange rate in Brazil and on domestic interest rates. What is the relation between these rates and the fiscal variables? For Brazil, primary balances and spreads show a non-stable association (Figure 2). From 1994 to 1998, when fiscal balances deteriorated, spreads declined. After 1999, when fiscal balances improved, spreads declined further. Drudi and Prati verified this non-monotonic relationship in their study of several European countries. The relationship between public debt and spreads is also non-monotonic. From 1994-1997, when the debt ratio was low and slightly rising, spreads fell. Since 1999, however, Brazilian spreads and debt ratios appear to have settled at a higher level (Figure 3). Drudi and Prati (DP) described a similar phenomenon for the European countries.

Figure 2

Primary Fiscal Balances and Sovereign Spreads in Brazil 1994-2003

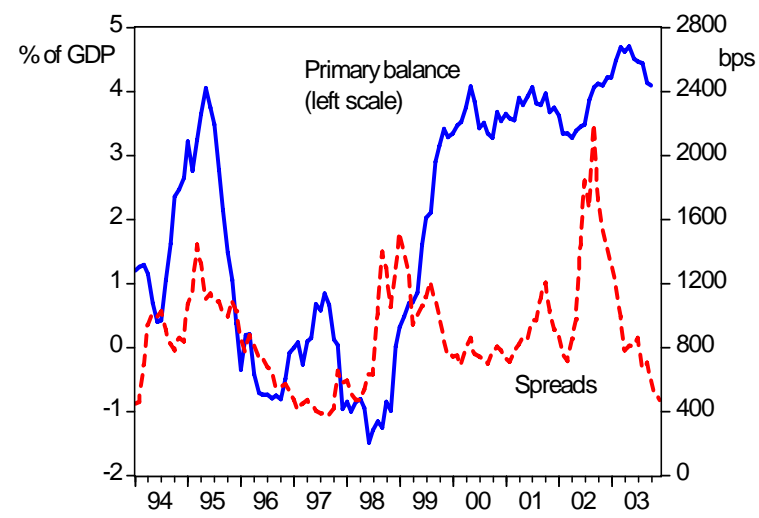

Figure 3

Public Debt Ratio and Sovereign Spreads in Brazil $1994-2003$

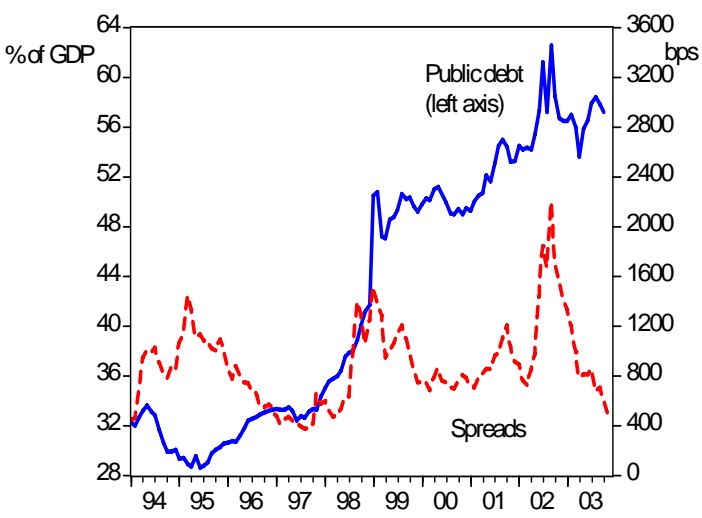

The DP model predicts that the primary fiscal balances and public debt ratios enter the rating (spreads) function, and that the primary balance has a more influential role when debt ratios are high. This section verifies econometrically the following three testable implications of the DP model: 1) Debt ratios and primary balances are complementary in the spreads function; 2) The signaling role of the primary balance increases with the debt ratio; and, 3) If the government is dependable, then the primary balance will rise when the debt ratio increases.

To verify the complementary role of fiscal balances and debt ratios in the spreads function, we regressed the sovereign spreads on the first two variables (lagged). Table 2 shows that both variables enter significantly in the spreads function with the expected signs. 
Table 2

Complementary Roles of Debt Ratios and Primary Balances as Spreads' Determinants

Dependent Variable: EMBORLAT

Method: Least Squares

Sample(adjusted): 1995:02 2002:01

Included observations: 84 after adjusting endpoints

Newey-West HAC Standard Errors \& Covariance (lag truncation=3)

\begin{tabular}{lrrrr}
\hline \multicolumn{1}{c}{ Variable } & Coefficient & Std. Error t-Statistic & Prob. \\
\hline \multicolumn{1}{c}{ C } & -0.26 & 0.06 & -4.45 & 0.00 \\
\multicolumn{1}{c}{ PRIMBY(-1) } & 0.01 & 0.00 & 4.48 & 0.00 \\
& -0.02 & 0.01 & -2.40 & 0.02 \\
\hline \hline R-squared & 0.454 & Mean dependent var & -0.011 \\
Adjusted R-squared & 0.441 & S.D. dependent var & 0.083 \\
S.E. of regression & 0.062 & Akaike info criterion & -2.698 \\
Sum squared resid & 0.309 & Schwarz criterion & -2.611 \\
Log likelihood & 116.295 & F-statistic & 33.723 \\
Durbin-Watson stat & 0.362 & Prob(F-statistic) & 0.000 \\
\hline \hline
\end{tabular}

EMBORLAT= Brazil EMBI spreads orthogonalized from Latin EMBI average

DEBTY = Debt to GDP ratio

PRIMBAL= Primary fiscal balance

The second implication of the DP model, namely the changing nature of the signaling role of primary balances, is captured by two alternative approaches. First, a dummy variable is defined for a specific signaling period and interacted with the primary balances. The original regression is augmented with this new auxiliary variable, and the sum of both coefficients has to be larger than the primary balance coefficient by itself. For the second approach, an auxiliary variable is constructed by the interaction of the primary balances with the debt ratio. If this variable is significant, then the hypothesis of the difference in the signaling role cannot be rejected.

For the first approach, we defined the signaling period from June 1999 to the time when the inflation-targeting approach was adopted and the Fiscal Responsibility Law was enacted. Given the significance of this auxiliary variable (Table 3), we cannot reject the hypothesis that primary balances affected spreads more forcefully during this signaling period. The alternative approach (Table 4) shows that the primary balance coefficient rose with the debt ratio, implying that signaling takes time and is not a once-and-for-all event. Drudi and Prati obtained the same result for Italy and Belgium. 
Table 3

The Changing Role of Primary Balances-Test 1

Dependent Variable: EMBORLAT

Method: Least Squares

Sample(adjusted): 1995:02 2002:01

Included observations: 84 after adjusting endpoints

Newey-West HAC Standard Errors \& Covariance (lag truncation=3)

\begin{tabular}{|c|c|c|c|c|}
\hline Variable & Coefficient & Std. Error & t-Statistic & Prob. \\
\hline $\operatorname{DEBTY}(-1)$ & 0.013764 & 0.002046 & 6.726813 & 0.0000 \\
\hline PRIMBAL(-1) & 5.95E-05 & 0.005334 & 0.011153 & 0.9911 \\
\hline DSIG*PRIMBAL(-1) & -0.054382 & 0.012458 & -4.365126 & 0.0000 \\
\hline $\mathrm{C}$ & -0.500954 & 0.075216 & -6.660195 & 0.0000 \\
\hline R-squared & 0.641035 & \multicolumn{2}{|c|}{ Mean dependent var } & -0.011316 \\
\hline Adjusted R-squared & 0.627574 & \multicolumn{2}{|c|}{ S.D. dependent var } & 0.082535 \\
\hline S.E. of regression & 0.050368 & \multicolumn{2}{|c|}{ Akaike info criterion } & -3.092458 \\
\hline Sum squared resid & 0.202958 & \multicolumn{2}{|c|}{ Schwarz criterion } & -2.976705 \\
\hline Log likelihood & 133.8832 & \multicolumn{2}{|l|}{ F-statistic } & 47.62098 \\
\hline Durbin-Watson stat & 0.611709 & \multicolumn{2}{|c|}{ Prob(F-statistic) } & 0.000000 \\
\hline
\end{tabular}

All variables defined in preceding table

DSIG $=1$ for $\mathrm{t}>$ January 1999; 0 otherwise

\section{Table 4}

The Changing Role of Primary Balances-Test 2

Dependent Variable: EMBORLAT

Method: Least Squares

Sample(adjusted): 1995:02 2002:01

Included observations: 84 after adjusting endpoints

Newey-West HAC Standard Errors \& Covariance (lag truncation=3)

\begin{tabular}{|c|c|c|c|c|}
\hline Variable & Coefficient & Std. Error & t-Statistic & Prob. \\
\hline $\mathrm{C}$ & -0.530713 & 0.071481 & -7.424499 & 0.0000 \\
\hline $\operatorname{DEBTY}(-1)$ & 0.014446 & 0.001826 & 7.912960 & 0.0000 \\
\hline PRIMBAL(-1) & -0.024688 & 0.003926 & -6.288602 & 0.0000 \\
\hline PRIMBAL $(-1) *($ DEBTDEV $)$ & -0.002630 & 0.000572 & -4.593340 & 0.0000 \\
\hline R-squared & 0.632718 & \multicolumn{2}{|c|}{ Mean dependent var } & -0.011316 \\
\hline Adjusted R-squared & 0.618945 & \multicolumn{2}{|c|}{ S.D. dependent var } & 0.082535 \\
\hline S.E. of regression & 0.050949 & \multicolumn{2}{|c|}{ Akaike info criterion } & -3.069552 \\
\hline Sum squared resid & 0.207661 & \multicolumn{2}{|c|}{ Schwarz criterion } & -2.953799 \\
\hline Log likelihood & 132.9212 & \multicolumn{2}{|l|}{ F-statistic } & 45.93872 \\
\hline Durbin-Watson stat & 0.632039 & \multicolumn{2}{|c|}{ Prob(F-statistic) } & 0.000000 \\
\hline
\end{tabular}

DEBTDEV=Deviation of the debt ratio from the sample mean

The third and final implication of the DP model, the positive association between the primary balance and the debt ratio if the government is dependable is reflected in Table 5. 


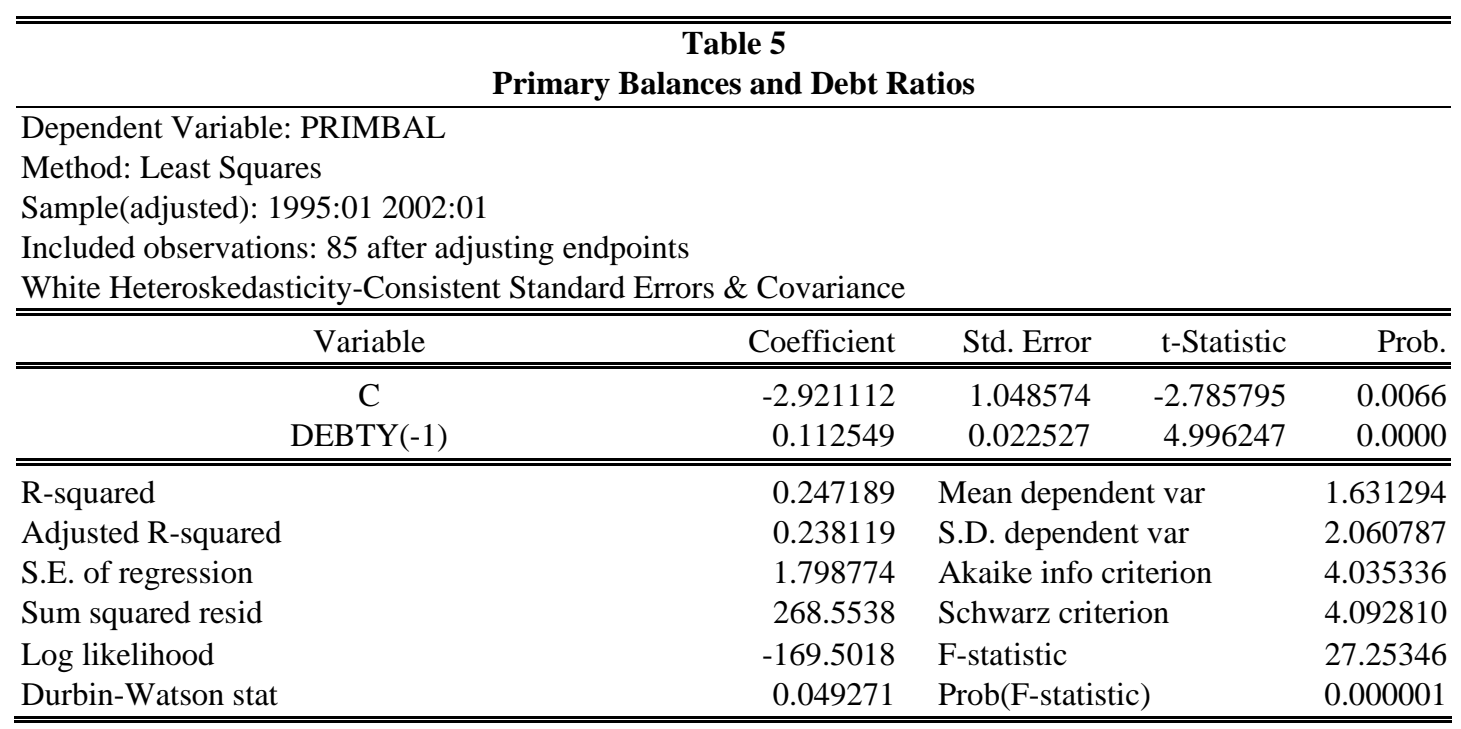

\section{The Type of Brazilian Fiscal Adjustment, 1999-2005}

During the first four years of the Real Plan (1995-98), fiscal accounts were imbalanced due mostly to the loss of inflation as an adjustment mechanism and to the lack of decisive fiscal reform. As Table 6 shows, the weaker fiscal stance registered during the1995-98 period is explained by rising expenditure, which grew by $16 \%$, with personnel and social security benefits expanding the most. Revenue rose just $8 \%$ or $1.4 \%$ of GDP, with growth concentrated on taxes, while the revenues of the Social Security System remained stable. In sum, the fiscal expansion of 1995-98 was caused by rising expenditure and not to revenue reduction.

The adjustment of the federal fiscal accounts in the last six years has been based on revenue increases and investment cuts. During 1999-2005, tax revenue rose by $4.6 \%$ of GDP. Spending also grew, but at a slower rate: it rose by 2.5 percentage points of GDP during 1999-2005. As in the 1995-98, current expenditure accounted for the bulk of the rise, while capital spending were reduced. In this case, personnel expenditures remained stable while social security benefits and intergovernmental transfers experienced more dramatic increases.

The revenue-increasing nature of the 1999-2003 fiscal adjustment raises concerns about its sustainability. International experience shows that revenue-based adjustments tend to be short-lived (Alesina and Peroti, 1996). As spending follows the rising revenue, the adjustment effort is weakened and the lasting effect is a larger government. 
Table 6: Federal Government Primary Surplus Changes, 1990 - 2005

\begin{tabular}{|c|c|c|c|c|c|c|c|c|c|c|c|}
\hline \multirow[t]{2}{*}{ Categories } & \multicolumn{3}{|c|}{ Annual Averages (\% of GDP) } & \multicolumn{4}{|c|}{ Variation 91/94 - 95198} & \multicolumn{4}{|c|}{ Variation 95/98 - 99105 } \\
\hline & $\begin{array}{c}1990-1994 \\
\text { (A) }\end{array}$ & $\begin{array}{c}19955.1998 \\
\text { (B) }\end{array}$ & $\begin{array}{c}1999-2005 \\
\text { (C) } \\
\end{array}$ & $(B) \cdot(A)$ & $\begin{array}{l}\text { Percentual } \\
\text { Variation } \\
\end{array}$ & Decompl & Decomp II & (C). (B) & \begin{tabular}{|c|} 
Percentual \\
Variation \\
\end{tabular} & Decomp I & Decomp II \\
\hline I Total Revenue & 17.3 & 18.6 & 23.2 & 1.3 & 7.7 & 102 & 100 & 4.6 & 24.6 & 222 & 100 \\
\hline Treasury Revenue & 11.9 & 13.6 & 18.0 & 1.7 & 14.6 & 132 & 130 & 4.3 & 31.8 & 210 & 95 \\
\hline Tax Revenue & 11.0 & 12.0 & 16.6 & 1.1 & 9.9 & 83 & 81 & 4.5 & 37.6 & 219 & 99 \\
\hline Other Treasury Revenues & 1.2 & 1.6 & 1.4 & 0.4 & 32.1 & 29 & 29 & $\cdot 0.2$ & -12.0 & .9 & .4 \\
\hline Social Security Revenue & 5.0 & 5.1 & 5.3 & 0.1 & 2.7 & 10 & 10 & 0.2 & 3.3 & 8 & 4 \\
\hline \|| Total Expenditure & 15.8 & 18.4 & 20.8 & 2.6 & 16.4 & .198 & 100 & 2.5 & 13.5 & .120 & 100 \\
\hline Personnel and Social Contributions & 4.4 & 5.2 & 5.1 & 0.7 & 17.0 & .57 & 29 & -0.1 & -1.3 & 3 & .3 \\
\hline Social Security Benefits & 4.2 & 5.4 & 6.7 & 1.2 & 30.0 & .95 & 48 & 1.3 & 23.4 & 61 & 51 \\
\hline Other Current and Capital Expenditures & 4.3 & 4.8 & 5.2 & 0.5 & 11.1 & .36 & 18 & 0.4 & 8.3 & -19 & 16 \\
\hline Subsidies & 0.1 & 0.2 & 0.3 & 0.1 & 98.2 & .8 & 4 & 0.1 & 51.3 & .5 & 4 \\
\hline FAT & 0.2 & 0.6 & 0.6 & 0.3 & 138.7 & .25 & 12 & 0.0 & 2.4 & -1 & 1 \\
\hline Other- Goods and Services and Investment & 4.0 & 4.0 & 4.3 & 0.0 & 1.1 & .3 & 2 & 0.3 & 6.8 & $\cdot 13$ & 11 \\
\hline Intergovernmental Transfers & 2.9 & 3.0 & 3.9 & 0.1 & 3.9 & .9 & 4 & 0.9 & 29.4 & -43 & 36 \\
\hline Primary Balance $(1 \cdot \|)$ & 1.6 & 0.3 & 2.4 & $\cdot 1.3$ & 81.7 & 100 & & 2.1 & 708.1 & 100 & \\
\hline
\end{tabular}

$D$. The rigidity of expenditure as the main explanation of the type of adjustment

Fiscal adjustment was revenue-based because of the rigidity of public spending. At the federal level, this rigidity is caused by three factors: i) the rise of social security and social assistance benefits; ii) the job tenure stability rules for public servants made impossible reducing the public sector payroll; and, iii) the constitutional earmarking of an important part of federal tax revenues.

The 1988 Constitution reinforced the three factors of expenditure rigidity through the concession of higher social security benefits and softening the eligibility criteria, defining a generous regime for official public employees which included job tenure and higher compensation and pension benefits equal to $100 \%$ of exit salaries, extending these benefits to all public sector employees and strengthening the intergovernmental transfers system. The 1988 Constitution favored the expansion of social responsibilities of the state, guaranteeing free access to social services, particularly health services, creating the unemployment insurance, establishing minimum social security benefits (1 minimum wage), and universalizing it by extending coverage to rural workers.

Figure 4 shows the rising share of mandatory spending between 1986 and 2003. The increasing rigidity is due to the rise of personnel, social security and assistance transfers, and the intergovernmental transfers to states and municipalities that increased from 55\% of non-financial expenditure in 1986 to almost 80\% in 2003. 


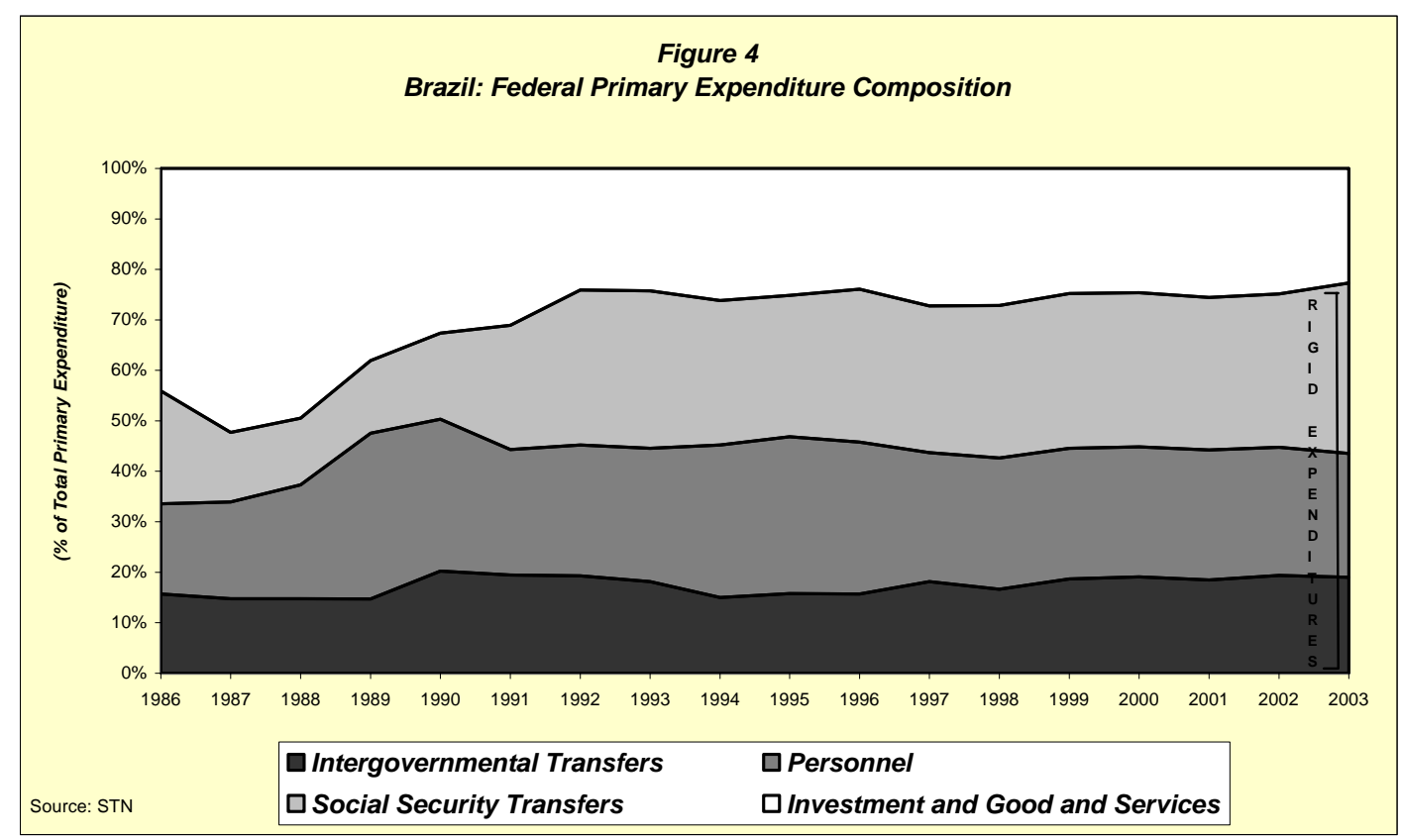

As a result of the growing share of mandatory spending, investment and other current expenditures decreased their share from around $51 \%$ of primary expenditure to less than $20 \%$ in 2001 . Clearly, social security transfers are the fastest-increasing type of expenditure, generating a huge deficit that has to be covered by the Treasury. Figure 5 shows the evolution of the social security system imbalances during the period 19902005. In 1990 the deficit was $1.4 \%$ of GDP in 2005 it reached $5.7 \%$ becoming the most important source of pressure for government accounts.

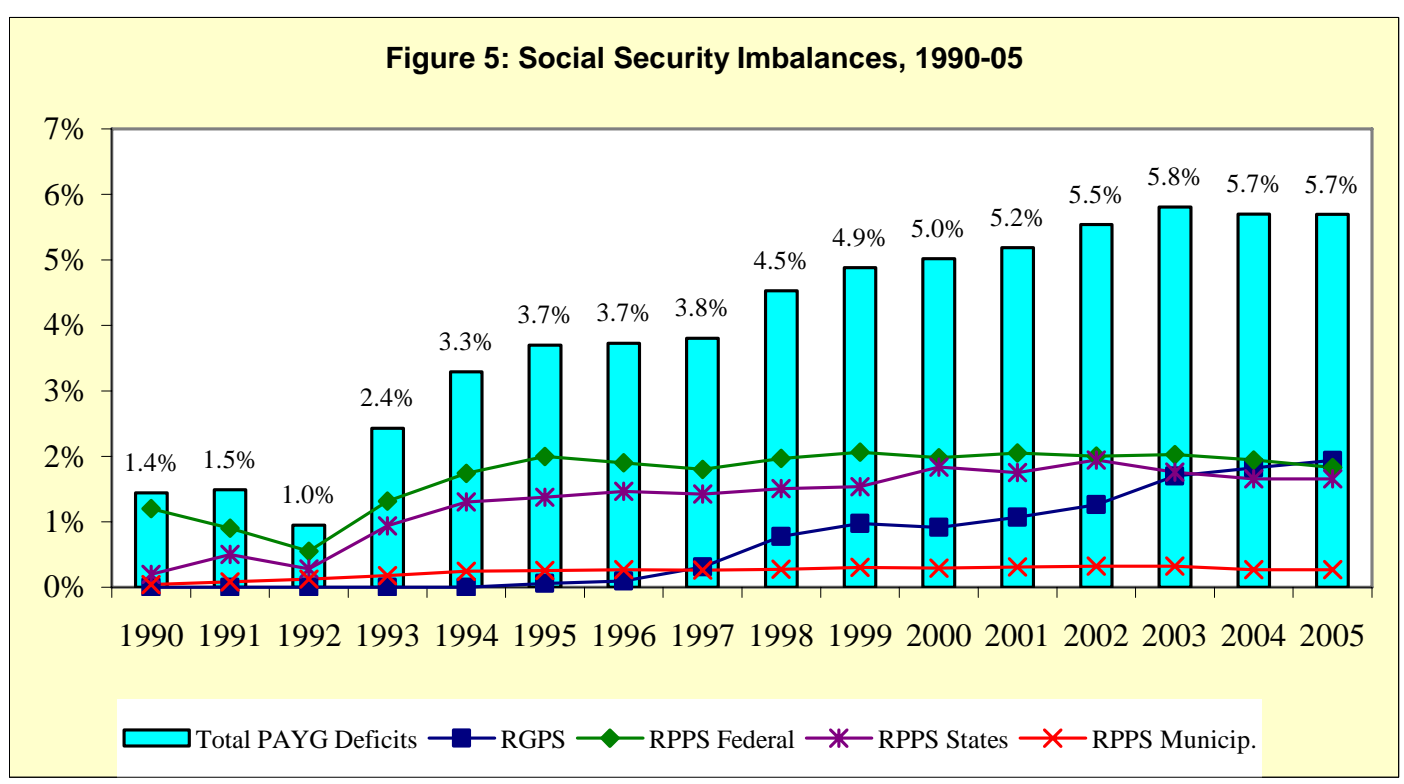




\section{Policy Rigidity and the 2002 Crisis}

In sharp contrast with the 1998-1999 adjustment, Brazil's fiscal policy did not react to the shocks in early 2002. This policy rigidity compounded uncertainty arising from other sources and led to asset price changes that complicated the situation even more. The government's commitment to maintain a constant primary surplus seemed to falter as the primary balance declined during the first semester (Figure 6) amidst a heated political debate on the stance of future fiscal policy.

Figure 6

Primary Fiscal Balance of the Public Sector 2000-2003 (as a percentage of GDP)

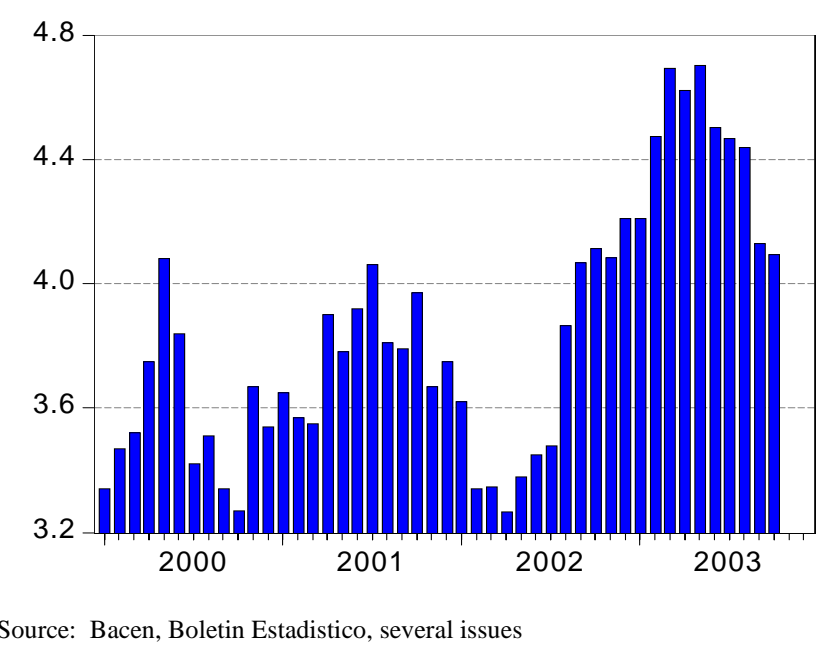

The rigidity of fiscal policy may have been at the root of the 2002 crisis. Inflexibility was the result of structural factors and transitory circumstances. The structural inflexibility of the budget exists in expenditures as discussed in the previous section. But fiscal policy rigidity was also due to the short-term effect of the October presidential elections. The government's coalition had weakened because of internal disputes in anticipation of the presidential election. Additionally, corruption allegations in congress led to the impeachment of its president, a strong supporter of the government's economic policy. In this context, crucial reforms with fiscal impact, such as the public servants social security and tax reform, were left pending. Other reforms, such as the extension of the financial transactions tax, the CPMF, stalled. With the political campaign heating up in the first quarter, it was practically impossible to get support for any adjustment. Additionally, any change would have been interpreted as transitory given that a new government would take office in the near future.

Uncertainty regarding the future government's commitment to fiscal adjustment (irrespective of who won the election) generated concerns about the future value or liquidity of public debt. Given the concentration of public debt holdings in mutual funds (to be discussed in the next section), a large resource outflow affected them in the period April-October. In its peak, the run represented more than 6 percent of the intermediaries' net worth (Figure 7). 
Figure 7

Net Resource Flow to Mutual Funds

(as a fraction of net worth)

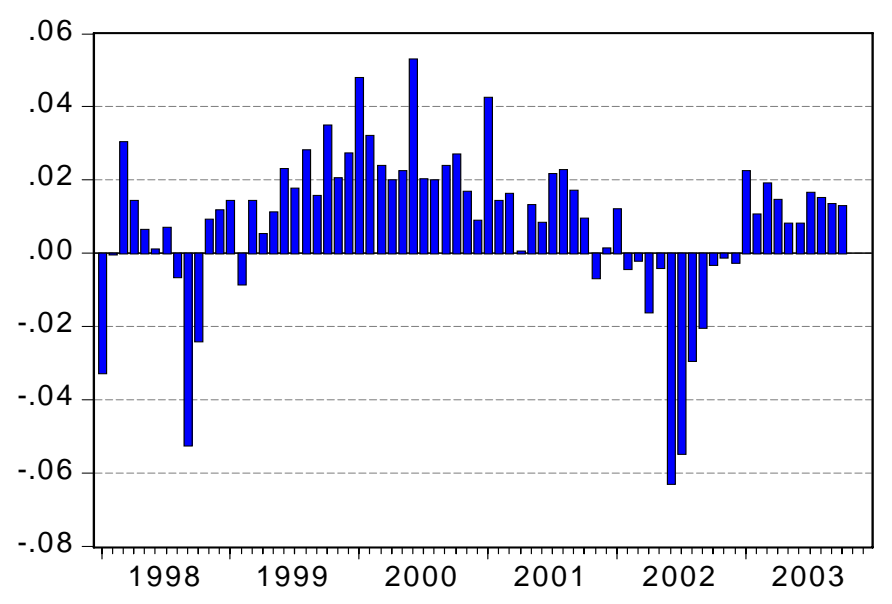

The sell-off of government securities caused a fall in their price (rising spreads), and pressured the exchange rate to depreciate (Figure 8). The rising spreads and the exchange rate depreciation were also associated with capital outflows from Brazil. As Figure 9 shows, in September and October of 2002, capital outflows reached a peak of almost 20 percent of international reserves of the central bank. ${ }^{4}$ During these months the exchange rate also reached a peak of 4 Reais per dollar. Consequently, the debt level rose due to its indexing to the exchange rate. This fact aggravated concerns on debt sustainability which exerted further downward pressure on the demand for Brazilian sovereign bonds and pushed their prices even lower in a vicious circle.

Figure 8

Brazilian Spreads and Exchange Rate Jan 2000 - April 2003

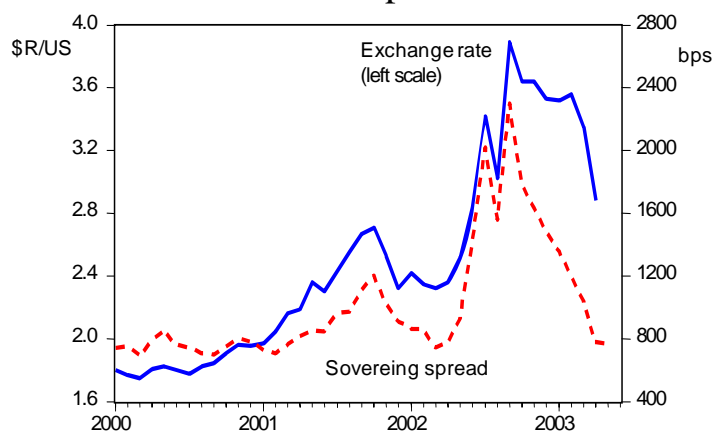

Figure 9

Capital Flows to Brazil (ratio to international reserves

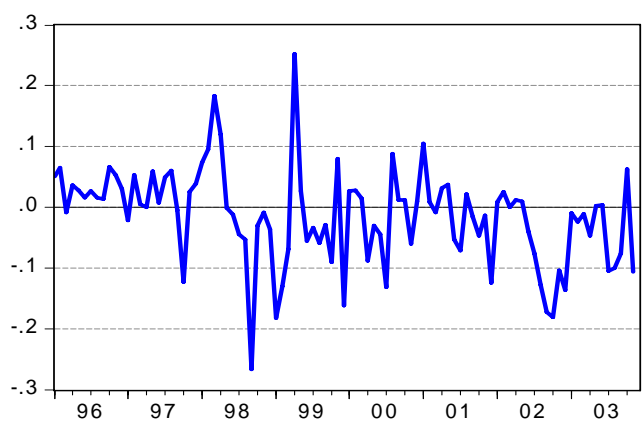

Source: Bacen and JP Morgan

\footnotetext{
${ }^{4}$ Capital flows exclude foreign direct investment and IMF resources.
} 
The fall of Brazilian government securities' prices and capital outflows also occurred because of a global phenomenon: the rise in uncertainty and risk aversion caused by the growth slowdown in the industrialized nations, the terrorist attacks in the United States, and the corporate corruption scandals of the more mature capital markets around the world. This fact exerted additional downward pressure on Brazilian government bonds, and their prices moved in tandem with those of other assets worldwide (Figure 10). Favero and Giavazzi (2003) show how Brazilian spreads depend on domestic factors (the stance of fiscal policy) and on global conditions. The relationship is non-linear: when domestic fundamentals are sound, this relationship is not as strong, but when fiscal fundamentals are weak, the effect of global factors is amplified.

Figure 10

Co-movement of Brazil C Bond Prices and the Dow Jones Index Evidence of Global Factors' Influence on Brazilian Asset Prices

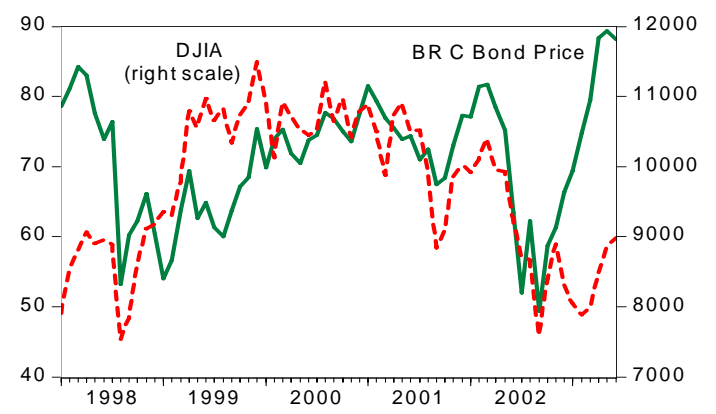

Source: World Bank staff calculations

Faced with mounting difficulties in rolling over the domestic debt, the central bank redeemed a fraction of debt falling due by printing money. Consequently, the monetary base expansion exceeded nominal GDP growth (Figure 11). The monetary effect of public domestic debt redemptions during the second semester of 2002 reached the tenor of 30 percent of base money (Figure 12). It is crucial to point out, however, that the monetary expansion originated by the treasury's operation began in the second semester of 2001 and could have been interpreted as a leading indicator of the more turbulent episodes that were to unravel in mid 2002. 
Figure 11

Money Base as a Share of GDP

(seasonally adjusted data

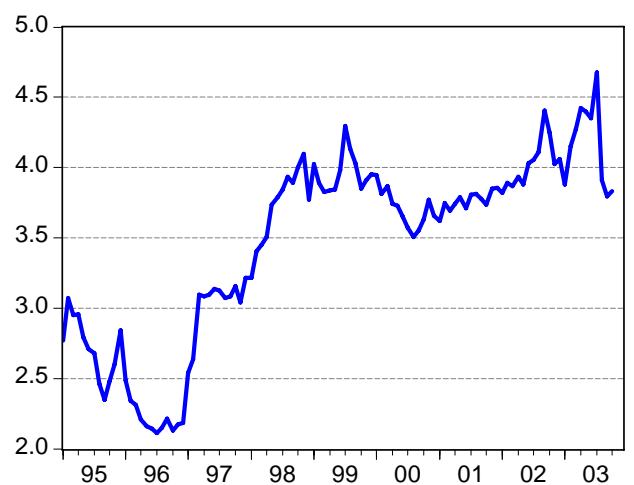

Source: World Bank staff calculations based on Bacen data
Figure 12

Monetary Impact of Treasury's

Operations 1999- 2003

(ratio to the monetary base

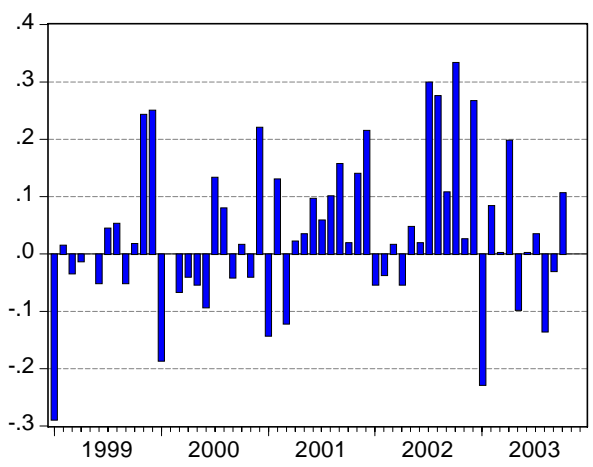

Source: World Bank calculations based on Bacen data

Moreover, base money grew in lockstep with the faster depreciation of the currency. This pressured inflation, which accelerated between June and December, reaching a peak of 5.8 percent per month in November (Figure 13). Monetary growth and rising inflation increased the government's revenue from money creation up to the equivalent of 2.0 percent of $\mathrm{GDP}^{5}$ (Figure14). In these circumstances, the authorities' credibility faltered. It is interesting to note that the seignorage peak occurred in the first quarter of 2003, a few months after the public debt ratio had stabilized and the exchange rate had appreciated. This implies that interest rates could not be lowered as quickly as many would have desired.

Figure 13

Monthly Inflation Rate in Brazil 2000-2003 (seasonally adjusted General Price Level

IGP-DI)

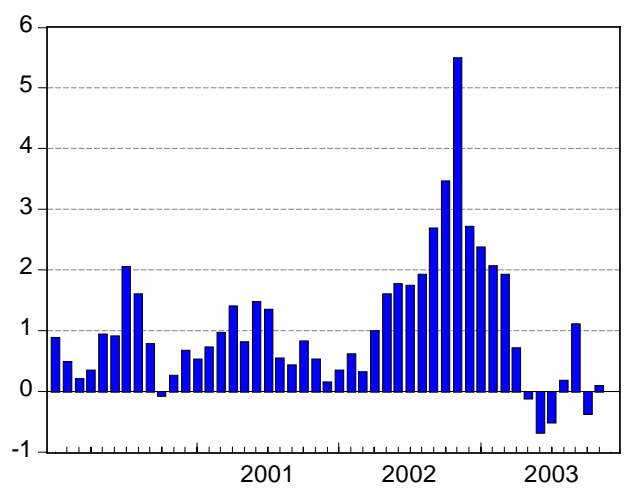

Source: FGV
Figure 14

Seignorage from Money Creation

2000-2003

(\% of GDP)

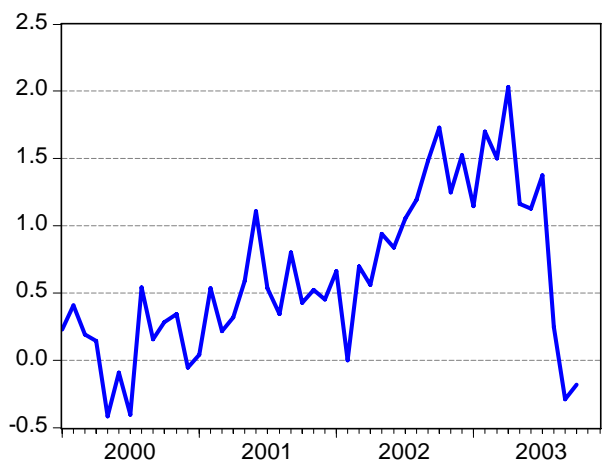

Source: World Bank calculations described in text.

\footnotetext{
${ }^{5}$ The figures reported in the text and in the graph are estimated by multiplying the base money as a share of GDP times the growth rate on base money. Eliana Cardoso (1998) estimates the average inflation tax revenue in Brazil during the 50 years ending 1995 at 2 percent of GDP.
} 
The monetary authorities reacted variously to the shocks during 2001-2002. Initially, from March 2001 to July 2001, the central bank raised the Selic rate from 15.25 percent to 19 percent. From then on, it maintained the Selic at 19 percent, until February 2002, when it reduced it 25 bps, then lowered it again in March and July. In mid-October 2002, the central bank bumped up the Selic three percentage points to 21 percent and then raised it two more times until reaching 25 percent before the year's end (Figure 15). As the Selic rose, the exchange rate partially reversed its depreciating trend, and the debt stock (as a percent of GDP) decreased. Looking (ex-post) at this behavior, it is legitimate to wonder why the central bank did not raise interest rates before October.

Several factors might explain the central bank delayed reaction and some are related to considerations described by Blanchard's model. The first reason is that, before September-October, the fiscal conditions were inadequate. Public debt to GDP increased from 49 percent to 53 percent in 2001, and climbed further to 57 percent by mid-2002 without any policy response. With the primary balance decreasing during the first semester of 2002, it is understandable that sustainability concerns dominated investor sentiment. ${ }^{6}$ With taxes and expenditures predetermined by the electoral process and the structural rigidity of the budget, the adjustment of the government's real cash flow could come through several avenues: an increase in the price level, a higher seignorage, or a default. The nature of the fiscal regime could have switched from one in which the primary surplus would be adjusted with certainty to ensure debt sustainability to one where there was uncertainty on how the adjustment would take place. A-priori it was difficult to envision how the adjustment would take place, and the composition of public debt, which we discuss in the following section, determined the final outcome.

The crucial point to bear in mind is that, under the circumstances of rising debt levels with an unresponsive fiscal policy, raising the Selic could have been inflationary. ${ }^{7}$ The higher cost of debt service (with an unresponsive primary surplus) would have led to a higher probability of default. This, in turn, would have accelerated capital outflows, increasing pressure on the currency to depreciate and hence, on inflation. Since printing money and higher prices were part of the solution to the imbalance in the government's present-value borrowing constraint, fiscal expectations were inconsistent with a stable price level. In fact, since September 2001 inflation expectations were permanently above the central bank's central target and by mid-2002 market expectations of inflation were regularly above the forecasts of the more robust models (Minella, et.al. 2003). Additionally, there is evidence of changes in the price formation mechanism in Brazil at the end of 2002 that researchers attribute to changes in the exchange rate pass-through (Belaisch, 2003). However, these changes in the observed price formation and inflation

\footnotetext{
${ }^{6}$ This is what Blanchard calls the "wrong" fiscal conditions. Woodford (2001) call this a non-Ricardian environment. A Ricardian environment is one in which expected future primary surpluses adjust to compensate variations in the present value of debt, while in non-Ricardian regimes this policy adjustment certainty is non-existent.

${ }^{7}$ Woodford (2001) shows how the price level may be determined by fiscal variables. The government's inability to balance its budget constraint via adjustments in the primary surplus implies that the price level is the adjustment mechanism. Hence, the budget constraint acts as an equilibrium condition which determines a unique price level associated with the particular fiscal policy. Previous episodes of Brazilian inflation in the 1970's and 1980s have been explained based on these grounds (Loyo, 1999). The FaveroGiavazzi and Blanchard papers extend this theory to allow the price of debt (or the sovereign risk premium) to be the adjusting factor.
} 
expectations generating mechanisms could have also been the result of the changes in fiscal expectations arising from a different fiscal regime during this brief period.

Empirical verification of the nature of the prevailing fiscal policy regime in a particular period poses challenges both from the conceptual and practical viewpoints. At the conceptual level, verification of the nature of the fiscal regime would require testing whether the primary surplus would have been the same if another price sequence would have been observed. ${ }^{8}$ Unfortunately, history only shows the actual one realization of the price level and hence it is impossible to verify whether the surplus would have been the same with a different price sequence (Woodford, 2001; Kocherlakota et al., 1999).

At the more practical level, verification of the character of the fiscal regime focuses on testing the responsiveness of the primary balance to changes in different variables (Bohn, 1998). These tests perform regressions of the primary surplus on the public debt ratio and other control variables to verify the significance of this particular coefficient. A positive (and significant) response of the primary surplus to changes in the debt ratio implies that this policy variable was the adjustment factor. In Brazil, the brevity of the period during which this regime change might have occurred, limits any statistical testing. There are, however, studies that test this hypothesis using longer sample periods, with results extremely sensitive to the period of analysis. For instance, two papers report contradictory evidence: Favero and Giavazzi show that the primary surplus is highly persistent and unresponsive to any oscillation in the debt level; Wyplosz concludes that the observed surplus was similar to the one that would have resulted if the government had followed a rule that tried to stabilize the debt ratio while allowing some counter-cyclical action. It is very likely that this divergence obeys to the different sample periods: while the first study estimates the relationship after July 1999, the second one begins in 1998. Since there is a regime shift in fiscal policy in 1998-1999 described elsewhere (World Bank, 2000) and verified econometrically, the Favero-Giavazzi paper does not capture this change.

The second explanatory factor for the central bank's resistance to raise the policy rate was the vulnerable situation of mutual funds. Given the run on mutual fund deposits, raising the Selic would have been extremely risky because of the potential to aggravate losses to these intermediaries. Mutual funds were registering losses due to updating their balance sheets with new mark-to -market regulation from the central bank. Raising the Selic would have increased the risk of a generalized run on the system. Additionally, in the face of a decreased demand of public bonds, to be described in the next section, the central bank was supporting the price of these assets. Under this extraordinary circumstances imposed by the public bond price support role, equivalent to an interest rate peg, liquidity was endogenous, and hence it would have been contradictory to try to control liquidity (by raising the Selic). ${ }^{9}$ Given that monetary policy was unable to

\footnotetext{
${ }^{8}$ In a controlled experiment situation, if another price (of goods or of sovereign debt) sequence could be associated with the same fiscal policy, then the hypothesis could be falsified. However, in reality we only observe the actual price sequence and, hence, cannot tell whether the fiscal policy would have been the same under a different price sequence.

${ }^{9}$ The Brazilian circumstances of a fixed primary surplus, and a central bank acting to support the price of public bonds ( peging the interest rate) fit perfectly Woodford's characterization of the typical nonRicardian regime (Woodford, 1998, 2001), with the implication of the effect of fiscal expectations on the price level.
} 
respond, it would have been desirable that fiscal policy had been more responsive to the shocks.

By October 2002, the characterization of the economy had changed in several respects: (1) the run on mutual funds had been contained; (2) the presidential candidates had already agreed on sound fiscal policy principles; (3) the primary surplus reversed its decreasing trend and rose to unsurpassed levels. Clearly, the factors that originated the "wrong" expectations were not present any more. The central bank was then free to raise interest rates and quickly moved in this direction, bringing about the expected traditional results of the currency appreciating in response to tighter monetary policy as described in Figure 15. Control of the economy was gradually regained and consolidated after the first quarter of 2003.

Figure 15

Short-term policy interest rate (Selic) and exchange rate in Brazil 2000 - 2003

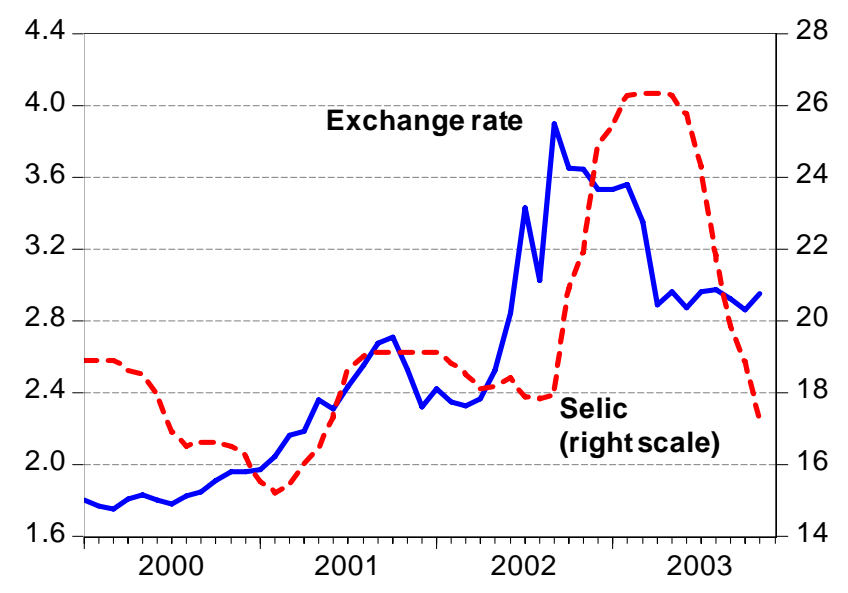

Source: Bacen

\section{Procyclical Fiscal Policy in Brazil}

The vicious circle of procyclical fiscal policy, volatility and limited creditworthiness has been amply documented for Latin America (Gavin, Hausmann, Perotti and Talvi, 1996). Pro-cyclical fiscal policy is explained by the following factors: a) limited access to international credit markets during a shock implies that countries are unable to follow a tax-smoothing approach and have to tighten fiscal policy; b) tax structures that are heavily dependant on cyclical-sensitive income, such as indirect taxes (Gavin and Perotti, 1997); and c) weak institutional structures that do not allow generation of large enough primary surpluses in good times and lead to increased spending during expansionary phases (Talvi and Vegh, 2000). Several authors have attempted to documented the procyclical nature of Brazil's fiscal policy ( IMF, WEO, 2002) but results are not very robust.

To examine the relationship between the primary balance and economic activity in the short and in the long run, we adopted the Autoregressive Distributed Lag (ARDL) 
approach (Pesaran and Shin, 1999, and Pesaran, Shin and Smith, 1999) because it is robust to the order of integration and cointegration of the regressors, hence the pre-testing procedures may be avoided. This approach also has the advantage that the lags in each of the regressors are allowed to be different, and the endogeneity problem can be eliminated by appropriate selection of the lag length (Pesaran and Shin, 1999).

Table 7

Estimated Long-Run Coefficients for the Primary Balance 1991:01 - 2002:01

\begin{tabular}{|l|l|l|l|l|}
\hline & AIC & RBSC & SBC & HQC \\
\hline Debt to GDP ratio & $.14^{*}$ & $.15^{*}$ & $.14^{* *}$ & $.12^{* * *}$ \\
& $(.05)$ & $(.05)$ & $(.07)$ & $(.07)$ \\
\hline Output (in logs) & $18.3^{*}$ & $20.8^{*}$ & $21.2^{*}$ & $18.0^{*}$ \\
& $(5.6)$ & $(5.6)$ & $(6.9)$ & $(6.5)$ \\
\hline REER (in logs) & $-7.6^{*}$ & $-7.6^{*}$ & $-8.96^{*}$ & $-9.8^{* * *}$ \\
& $(1.9)$ & $(1.8)$ & $(2.71)$ & $(2.57)$ \\
\hline Real interest rate & $-.01^{* * *}$ & $-.01^{* *}$ & $-.01^{* *}$ & $-.01^{*}$ \\
& $(.004)$ & $(.003)$ & $(.008)$ & $(.004)$ \\
\hline Sovereign spreads (in logs) & .30 & .44 & .37 & .01 \\
& $(.65)$ & $(.65)$ & $(.89)$ & $(.84)$ \\
\hline $\begin{array}{l}\text { Standard error in (). *Significant at the } \\
\text { level }\end{array}$ & \multicolumn{5}{l}{01 level; ** Significant at the .05 level; *** Significant at the .10 } \\
\hline
\end{tabular}

Table 7 shows that, in the long run, output is positively correlated with the primary balance. However, Table 8 shows that, in the short run, the correlation is negative, implying that fiscal expansions are associated with primary balance reductions, and the primary balance increases during output contractions, verifying the pro-cyclical nature of fiscal balances. Another interesting result depicted in Table 7 is the positive and significant relationship between the primary balance and the public debt ratio. This fact may be interpreted as the result of a fiscally responsible sovereign that adjusts its primary to compensate changes in the debt ratio.

Finally, in this section we estimate the cyclical component of the primary balance by regressing this variable on the long-run components of each of the explanatory variables used in the previous exercise. The residual of such regression is the part of the primary balance explained by the transitory or cyclical components of each of the explanatory variables. Hence, we interpret this residual as the cyclical component of the primary balance (Figure 16). In general, we observe that this component fluctuates between plus or minus 1 percent of GDP, with the most recent levels close to lower bound. That is, at the end of 2003, the economic slowdown and other transitory fluctuations of variables affecting the primary balance had a negative impact of close to one percent of GDP, compared to the positive impact of more than one percent of GDP in early 2000. Given that the observed primary balance improved by .5 percent of GDP during the period, the structural balance improved by close to 1.5 percent of GDP. 


\begin{tabular}{|c|c|c|c|c|}
\hline \multicolumn{5}{|c|}{$\begin{array}{c}\text { Table } 8 \\
\text { Error-correction Representation for the Selected ARDL models 1991-2002 } \\
\text { Dependent variable: } d \text { Primary Balance }\end{array}$} \\
\hline & AIC & RBSC & SBC & HQC \\
\hline Error-correction term(-1) & $-.20^{*}$ & $-.21^{*}$ & $-.13^{*}$ & $-.14^{*}$ \\
\hline$d$ Primary(-1) & .04 & .02 & & \\
\hline$d$ Primary(-2) & $.17^{* *}$ & $.16^{* *}$ & & \\
\hline \multicolumn{5}{|l|}{$d$ Primary(-3) } \\
\hline Ddebty & -.014 & .007 & $.018^{* *}$ & $.017 * * *$ \\
\hline Ddebty(-1) & -.038 & -.013 & & \\
\hline Ddebty(-2) & -.027 & -.018 & & \\
\hline Ddebty(-3) & $-.081^{* * *}$ & $-.085^{*}$ & & \\
\hline DOutput & -1.87 & -1.7 & -1.27 & -1.5 \\
\hline$d$ Output(-1) & $-2.36 * * *$ & $-3.1^{* *}$ & & \\
\hline$d$ Output(-2) & $-3.18^{* *}$ & $-3.6 *$ & & \\
\hline$d$ Output(-3) & $-1.98 * * *$ & $-2.27 * *$ & & \\
\hline Dreer & -1.49* & -.39 & $-1.2^{*}$ & $-1.4^{*}$ \\
\hline \multicolumn{5}{|l|}{ DREER(-1) } \\
\hline \multicolumn{5}{|l|}{ DREER(-2) } \\
\hline \multicolumn{5}{|l|}{ DREER(-3) } \\
\hline Dselicr &.- .0004 & -.004 & $-.001 * *$ & .006 \\
\hline dSelicr(-1) & -.001 & -.009 & & \\
\hline dSelicr(-2) & .001 & & & \\
\hline \multicolumn{5}{|l|}{ dSelicr(-3) } \\
\hline Dembi & $.44 * *$ & $.45 * *$ & $0.4^{* *}$ & $.43^{* *}$ \\
\hline dEmbi(-1) & $-.66^{*}$ & $-.60 *$ & $-.67 * *$ & $-.63 *$ \\
\hline $\mathrm{dEmbi}(-2)$ & & -.00 & & \\
\hline \multicolumn{5}{|l|}{ dEmbi(-3) } \\
\hline R-Bar ${ }^{2}$ & .30 & .30 & .21 & .23 \\
\hline D.W. & 2.15 & 2.06 & 2.09 & 2.05 \\
\hline $\begin{array}{l}\text { * Significant at the } .01 \mathrm{le} \\
* * \text { Significant at the } .05 \mathrm{le} \\
* * * \text { Significant at the } .10\end{array}$ & & & & \\
\hline
\end{tabular}

Figure 16: Cyclical Component of the Primary Balance (in percent of GDP)

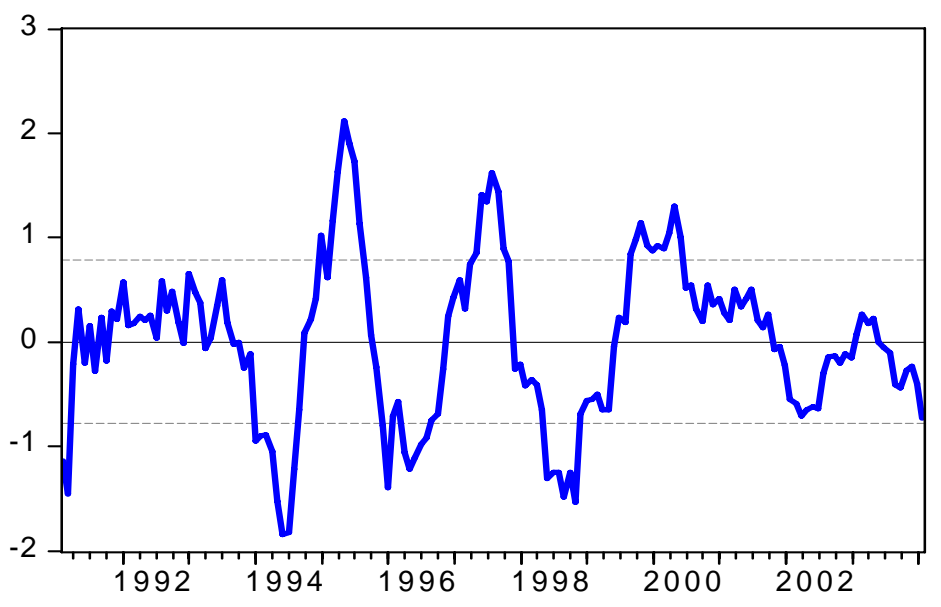




\section{Public Expenditure Composition and Growth}

In this section we estimate the long-run and short-run impact of government expenditure on Brazilian growth using two related methods. First, we use the singleequation ARDL methodology used in the previous section, and then we use a multipleequation co-integrating VAR approach to examine the relationship among the several variables.

Using data for 1950-2000, the Autoregressive Distributed Lag (ARDL) estimates a long run relationship and an error correction representation between income per capita, private and public capital stocks per capita and three components of government current expenditure (subsidies, social security and assistance transfers and consumption) ${ }^{10}$. The estimation also included tax revenues and public debt as a share of GDP to control for the government's budget identity and the potential negative effects of the government financing on economic activity. The data for the stocks of private and public capital were obtained from Reis et al (2002) and the flow data, that is income per capita and government current expenditures come from the National Accounts System - IBGE.

Tables 9 and 10 report the long-run coefficients and short-run dynamics estimated with this method. ${ }^{11}$ Table 9 shows that, in the long run the elasticity of output with respect to the public capital stock is larger than in that of the private sector. The estimated elasticity seems high when it is compared with estimated values for the US or OECD economies (Sturn and de Haan, 1995; Hurlin, 2001), but similar to existing Brazilian estimates for infrastructure (Cavalcanti, 2004). However, the negative impact of the tax ratio is surprisingly large: an increase of 1 percentage point in the tax ratio lowers GDP per capita by 1 percent.

\footnotetext{
${ }^{10}$ It also has the advantage that the lags in each of the regressors are allowed to be different, and the endogeneity problem can be eliminated by appropriate selection of the lag length (Pesaran and Shin, 1999)

${ }^{11}$ The tables report results for the different models: Akaika (AIC), Schwarz (SBC), R-Bar Squared (RBSQ) and Hanaan-Quinn (HQ). The production function was estimated in per capita terms, dividing all the arguments by the economically active population. There are 8 variables: GDP per capita, private capital stock per capita, public capital stock per capita, government subsidies, government consumption, government social security transfers, tax revenue ratio to GDP, and the public debt ratio to GDP. The maximum lag was 3 . This produced a total of 262,144 possible combinations: AIC, SBC and HQC selected an ARDL $(1,2,0,1,0,0,0,3)$ while the RBSC selected a $(1,2,1,1,0,1,0,3)$ model.
} 


\begin{tabular}{|c|c|c|c|c|}
\hline \multicolumn{5}{|c|}{$\begin{array}{c}\text { Table } 9 \\
\text { Estimated Long-Run Coefficients for the GDP per capita } \\
1950-2002\end{array}$} \\
\hline & AIC & RBSC & SBC & HQC \\
\hline Private Capital Stock per capita (in logs) & $\begin{array}{l}0.30^{*} \\
(0.10)\end{array}$ & $\begin{array}{l}0.29 * \\
(0.10)\end{array}$ & $\begin{array}{l}0.30^{*} \\
(0.10)\end{array}$ & $\begin{array}{l}0.30^{*} \\
(0.10)\end{array}$ \\
\hline Public Capital Stock per capita (in logs) & $\begin{array}{l}0.71 * \\
(0.11)\end{array}$ & $\begin{array}{l}0.72^{*} \\
(0.12)\end{array}$ & $\begin{array}{l}0.71^{*} \\
(0.11)\end{array}$ & $\begin{array}{l}0.71^{*} \\
(0.11)\end{array}$ \\
\hline $\begin{array}{l}\text { Gov. Expenditures: subsidies per capita (in } \\
\text { logs) }\end{array}$ & $\begin{array}{l}-0.04^{* *} \\
(0.02)\end{array}$ & $\begin{array}{l}-0.03^{* * *} \\
(0.02)\end{array}$ & $\begin{array}{l}-0.04^{* *} \\
(0.02)\end{array}$ & $\begin{array}{l}-0.04 * * \\
(0.02)\end{array}$ \\
\hline $\begin{array}{l}\text { Gov. Expenditures: consumption per capita (in } \\
\text { logs) }\end{array}$ & $\begin{array}{l}0.11 \\
(0.06)\end{array}$ & $\begin{array}{l}0.10 \\
(0.06)\end{array}$ & $\begin{array}{l}0.11 \\
(0.06)\end{array}$ & $\begin{array}{l}0.11 \\
(0.06)\end{array}$ \\
\hline $\begin{array}{l}\text { Gov. Expenditures: social security and } \\
\text { assistance transfers (in logs) }\end{array}$ & $\begin{array}{l}0.004 \\
(0.061)\end{array}$ & $\begin{array}{l}-0.04 \\
(0.07)\end{array}$ & $\begin{array}{l}0.004 \\
(0.061)\end{array}$ & $\begin{array}{l}0.004 \\
(0.061)\end{array}$ \\
\hline Tax Revenue to GDP Ratio & $\begin{array}{l}-1.01^{* *} \\
(0.37)\end{array}$ & $\begin{array}{l}-0.82^{* *} \\
(0.35)\end{array}$ & $\begin{array}{l}-1.01^{* *} \\
(0.37)\end{array}$ & $\begin{array}{l}-1.01 * * \\
(0.37)\end{array}$ \\
\hline Total Debt to GDP Ratio & $\begin{array}{l}0.30^{*} \\
(0.09)\end{array}$ & $\begin{array}{l}0.32 * \\
(0.08)\end{array}$ & $\begin{array}{l}0.30^{*} \\
(0.09)\end{array}$ & $\begin{array}{l}0.30^{*} \\
(0.09)\end{array}$ \\
\hline Constant & $\begin{array}{l}-0.29 \\
(1.00)\end{array}$ & $\begin{array}{l}0.03 \\
(1.12) \\
\end{array}$ & $\begin{array}{l}-0.29 \\
(1.00) \\
\end{array}$ & $\begin{array}{l}-0.29 \\
(1.00) \\
\end{array}$ \\
\hline Trend & $\begin{array}{l}-0.002 \\
(0.003)\end{array}$ & $\begin{array}{l}-0.001 \\
(0.003)\end{array}$ & $\begin{array}{l}-0.002 \\
(0.003)\end{array}$ & $\begin{array}{l}-0.002 \\
(0.003)\end{array}$ \\
\hline n ()$\cdot{ }^{*} S$ & 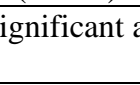 & 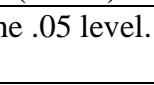 & 2 & 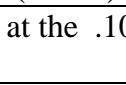 \\
\hline
\end{tabular}

Government expenditure in consumption or social security has no statistically significant effect on per-capita GDP, while subsidies have a negative impact. The positive effect of public debt ratio is somewhat puzzling and could reflect an endogeneity problem i.e. that as GDP per capita increases there is a larger demand for financial assets and public bonds is one of those assets that domestic agents demand. To examine this hypothesis, we used Granger causality tests and the Wu-Hausman exogeneity test and both lead to the non-rejection of the exogenous public debt hypothesis.

In the short run (Table 10) private capital has a greater impact on GDP per capita than the public capital. Government expenditures have no effect on GDP, and tax rates have a negative impact on GDP. Public debt has also negative impact on GDP per capita in the short-run.

The long run results are puzzling for two reasons. First, because the high public capital elasticity and, second, because the fact that the public sector elasticity is higher than the private one. This fact is also present in several of the classic studies for the US and OECD economies, such as Aschauer(1989), Ram and Ramsey (1989), Eisner (1994), Sturn and de Haan (1995), Balmaseda (1997) and Viverberg (1997). Hurlin (2001a, 2001b) shows that, in general, papers based on time series analysis of variables in levels, like the present one, tend to find large output elasticities of public capital. Hurlin shows that there are two potential sources of bias for this finding: a) the endogeneity of the factors of production, i.e. the fact that the productivity of private capital may depend on the level of public capital; and b) the fact that in most of those studies the output and the inputs are not cointegrated and the variables are non-stationary leading to the spurious regression problem. 
The first source of bias may not be a serious problem in this specific case, given the ARDL methodology produces consistent estimates of the long run coefficients (Pesaran an Shin, 1997). We tested for the correlation between both private and public capital and the residual of the regression, and were unable to reject the exogeneity of these variables. The second source of potential bias may be a problem, because based on the ARDL approach and the proposed method to test for long run relationships (Pesaran, Shin and Smith, 1999) the computed F-statistic between the upper and lower bounds that do not allow firm rejection or non-rejection of the null hypothesis of no long-run relationship.

\begin{tabular}{|c|c|c|c|c|}
\hline \multicolumn{5}{|c|}{$\begin{array}{c}\text { Table } 10 \\
\text { Error-correction Representation for the Selected ARDL models 1952-2002 } \\
\text { Dependent variable: } d \text { GDP per capita }\end{array}$} \\
\hline & AIC & RBSC & SBC & HQC \\
\hline Error-correction term (-1) & $\begin{array}{l}-0.52^{*} \\
(0.08)\end{array}$ & $\begin{array}{l}-0.57 * \\
(0.09)\end{array}$ & $\begin{array}{l}-0.52^{*} \\
(0.08)\end{array}$ & $\begin{array}{l}-0.52^{*} \\
(0.08) \\
\end{array}$ \\
\hline d(Private Capital Stock per capita) & $\begin{array}{l}1.66^{*} \\
(0.23)\end{array}$ & $\begin{array}{l}1.87 * \\
(0.27)\end{array}$ & $\begin{array}{l}1.66^{*} \\
(0.23)\end{array}$ & $\begin{array}{l}1.66^{*} \\
(0.23)\end{array}$ \\
\hline d(Private Capital Stock per capita)-1 & $\begin{array}{l}0.55^{* * *} \\
(0.28)\end{array}$ & $\begin{array}{l}0.63 * * \\
(0.31)\end{array}$ & $\begin{array}{l}0.55^{* * *} \\
(0.28)\end{array}$ & $\begin{array}{l}0.55^{* * *} \\
(0.28)\end{array}$ \\
\hline d(Public Capital Stock per capita) & $\begin{array}{l}0.37^{*} \\
(0.05)\end{array}$ & $\begin{array}{l}0.15 \\
(0.23)\end{array}$ & $\begin{array}{l}0.37 * \\
(0.05)\end{array}$ & $\begin{array}{l}0.37 * \\
(0.05)\end{array}$ \\
\hline d(Gov. Expenditures: subsidies per capita) & $\begin{array}{l}0.004 \\
(0.008)\end{array}$ & $\begin{array}{l}0.004 \\
(0.008)\end{array}$ & $\begin{array}{l}0.004 \\
(0.008) \\
\end{array}$ & $\begin{array}{l}0.004 \\
(0.008)\end{array}$ \\
\hline $\begin{array}{l}\text { d(Gov. Expenditures: consumption per } \\
\text { capita) }\end{array}$ & $\begin{array}{l}0.06 \\
(0.04)\end{array}$ & $\begin{array}{l}0.06 \\
(0.04)\end{array}$ & $\begin{array}{l}0.06 \\
(0.04)\end{array}$ & $\begin{array}{l}0.06 \\
(0.04)\end{array}$ \\
\hline $\begin{array}{l}\text { d(Gov. Expenditures: social security and } \\
\text { assistance transfers) }\end{array}$ & $\begin{array}{l}0.002 \\
(0.032)\end{array}$ & $\begin{array}{l}0.02 \\
(0.03)\end{array}$ & $\begin{array}{l}0.002 \\
(0.032)\end{array}$ & $\begin{array}{l}0.002 \\
(0.032)\end{array}$ \\
\hline d(Tax Revenue to GDP Ratio) & $\begin{array}{l}-0.53^{*} \\
(0.17) \\
\end{array}$ & $\begin{array}{l}-0.46 * * \\
(0.18) \\
\end{array}$ & $\begin{array}{l}-0.53^{*} \\
(0.17) \\
\end{array}$ & $\begin{array}{l}-0.53^{*} \\
(0.17) \\
\end{array}$ \\
\hline d(Total Debt to GDP Ratio) & $\begin{array}{l}-0.17^{* *} \\
(0.06)\end{array}$ & $\begin{array}{l}-0.16^{* *} \\
(0.06)\end{array}$ & $\begin{array}{l}-0.17^{* *} \\
(0.06)\end{array}$ & $\begin{array}{l}-0.17^{* *} \\
(0.06)\end{array}$ \\
\hline d(Total Debt to GDP Ratio)-1 & $\begin{array}{l}0.06 \\
(0.07)\end{array}$ & $\begin{array}{l}0.04 \\
(0.09)\end{array}$ & $\begin{array}{l}0.06 \\
(0.07)\end{array}$ & $\begin{array}{l}0.06 \\
(0.07)\end{array}$ \\
\hline d(Total Debt to GDP Ratio)-2 & $\begin{array}{l}0.24 * \\
(0.06)\end{array}$ & $\begin{array}{l}0.26^{*} \\
(0.06)\end{array}$ & $\begin{array}{l}0.24^{*} \\
(0.06)\end{array}$ & $\begin{array}{l}0.24 * \\
(0.06)\end{array}$ \\
\hline $\mathrm{d}$ (Constant) & $\begin{array}{l}-0.15 \\
(0.52)\end{array}$ & $\begin{array}{l}0.01 \\
(0.64)\end{array}$ & $\begin{array}{l}-0.15 \\
(0.52)\end{array}$ & $\begin{array}{l}-0.15 \\
(0.52)\end{array}$ \\
\hline d(Trend ) & $\begin{array}{l}-0.001 \\
(0.002)\end{array}$ & $\begin{array}{l}-0.001 \\
(0.002)\end{array}$ & $\begin{array}{l}-0.001 \\
(0.002)\end{array}$ & $\begin{array}{l}-0.001 \\
(0.002)\end{array}$ \\
\hline $\mathrm{R}^{2}$ & 0.88 & 0.89 & 0.88 & 0.88 \\
\hline D.W. & 1.99 & 1.92 & 1.99 & 1.99 \\
\hline
\end{tabular}

To examine further this potential problem, we adopted a multiple equation cointegrating VAR approach. This approach will also allow examination of relationships between variables that the single-equation ARDL approach did not allow. With the same set of variables, we were unable to reject the hypothesis of up to four cointegrating vectors. To reduce the dimensionality of the problem (and based on the variance decomposition) we excluded the debt variable and were able to reduce the number of cointegrating vectors to two. ${ }^{12}$

\footnotetext{
${ }^{12}$ See Appendix for the cointegration tests. One of the vectors, however, showed no persistence in the deviations from the equilibrium relationship to system-wide shocks. The other vector, on the contrary,
} 
With the specified system of six variables we examined the response of per capita GDP to multiple shocks with the Generalized Impulse Response Function. A one standard deviation shock to public capital (1.7 percent of GDP) that at the end of the simulation period (10 years) implies a higher public capital stock by almost 7 percent is associated with a 5 percent higher GDP (Figure 17); this fact implies a long-run elasticity of about .7, almost identical to the long run elasticity estimated by the single-equation (ARDL) method. This approach, however, has the advantage of allowing examination of the impact of this shock on other variables. For instance, such a shock to public capital is also associated with an increase in private capital of almost 5 percent by the end of the forecasting horizon (Fig.18) verifying some degree of complementarity between both types of capital.

A shock to private capital stock, representing a rise of six percent (in the long run) is associated with a higher GDP by 4 percent (Fig. 19). This would imply a long-run elasticity of about .6, much higher than the one estimated by the ARDL.

Figure 17

Generalized Impulse Response(s) to one S.E. shock in the equation for LKSTPUBP

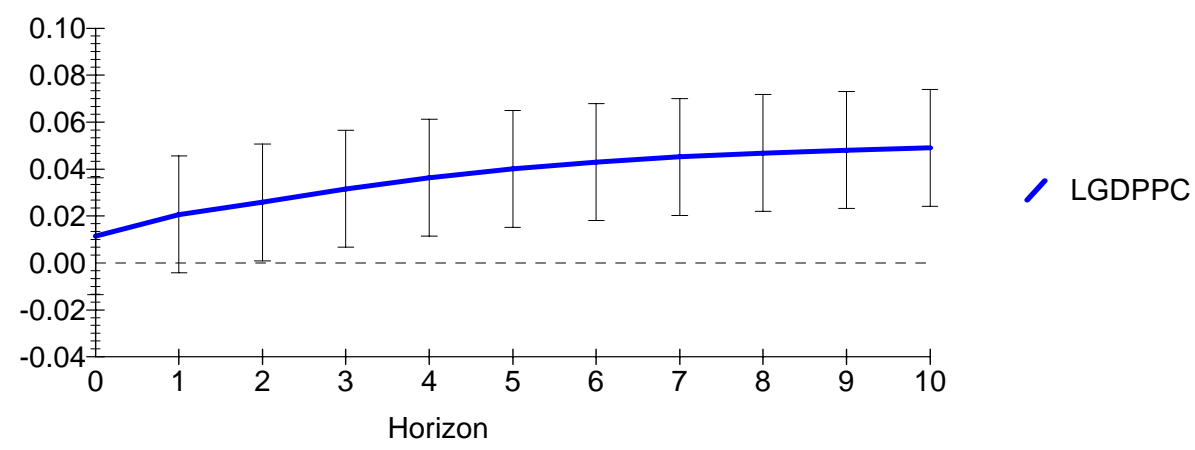

Figure 18

Generalized Impulse Response(s) to one S.E. shock in the equation for LKSTPUBP

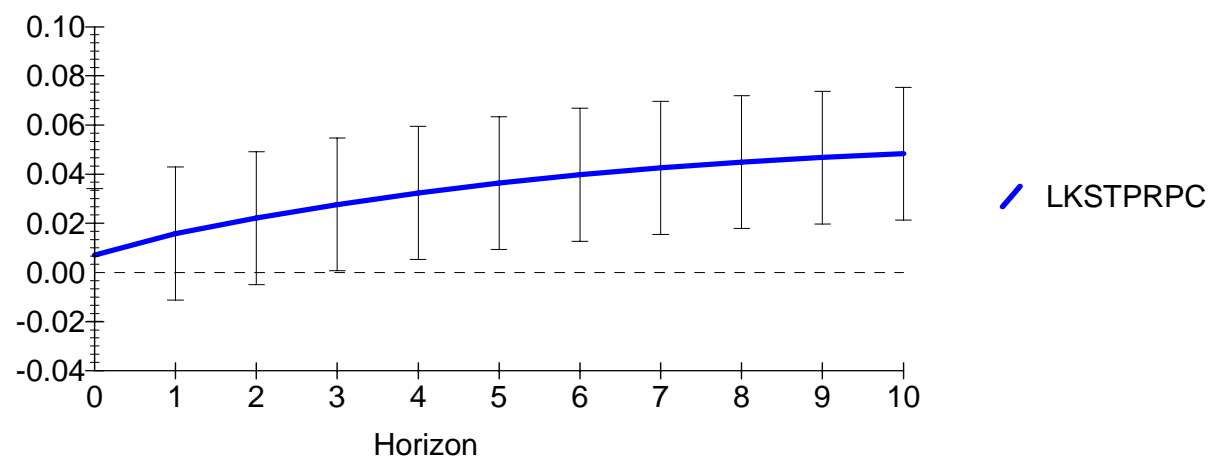

showed temporary deviations from the equilibrium relationship returning after a few years. We arbitrarily eliminated the first one and remained with a single cointegrating vector. 
Figure 19

Generalized Impulse Response(s) to one S.E. shock in the equation for LKSTPRPC

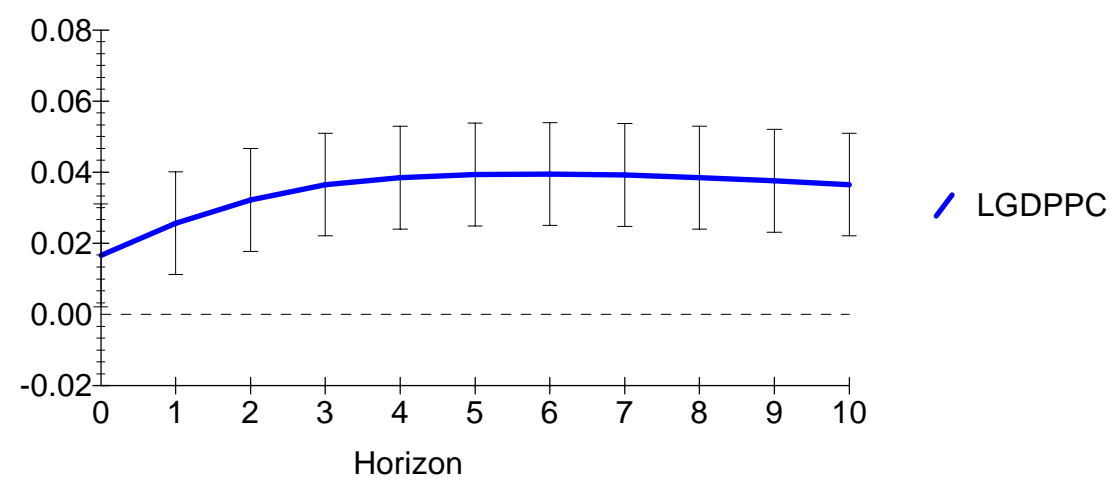

Another interesting result refers to the impact of a tax shock. A permanent increase of the tax ratio (of 1.5 percent of GDP) is associated with a lower GDP per capita of close to 1 percent (Figure 20), similar to the ARDL result. The same shock is associated with a lower private capital stock (Figure 21)

Figure 20

Generalized Impulse Response(s) to one S.E. shock in the equation for TOTTAXGD

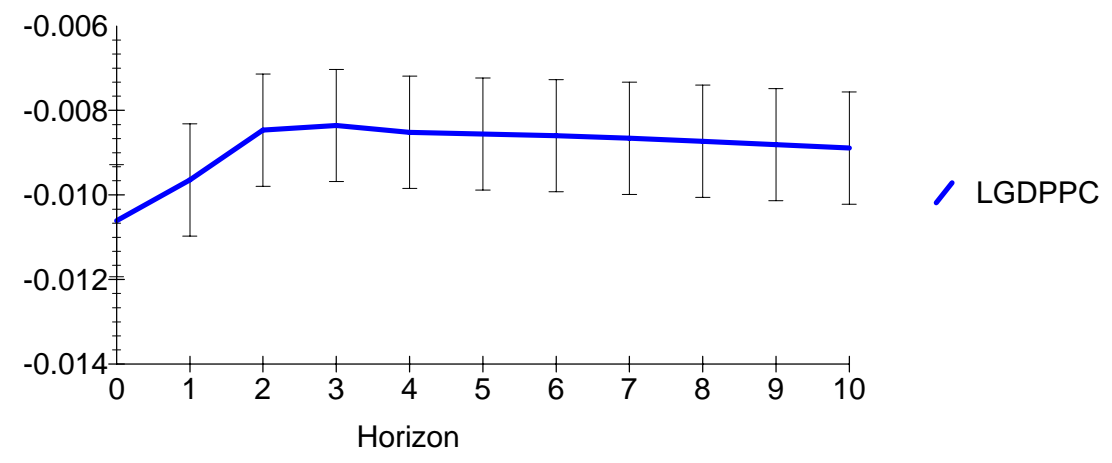

Figure 21

Generalized Impulse Response(s) to one S.E. shock in the equation for TOTTAXGD

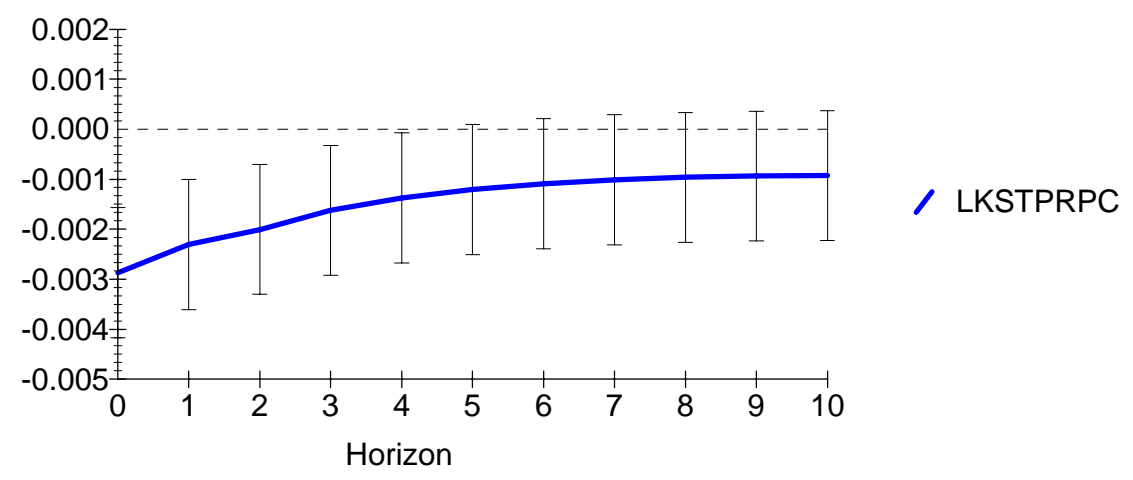

A shock that leads to a permanent rise of government consumption expenditure (of 7 percent in real terms) is associated with a fall in per capita GDP (Figure 22). This shock is associated with a higher tax ratio (Figure 23), lower private capital stock (Fig 24) and lower public capital stock as well (Figure 25). 
Figure 22

Generalized Impulse Response(s) to one S.E. shock in the equation for LGOVCONP

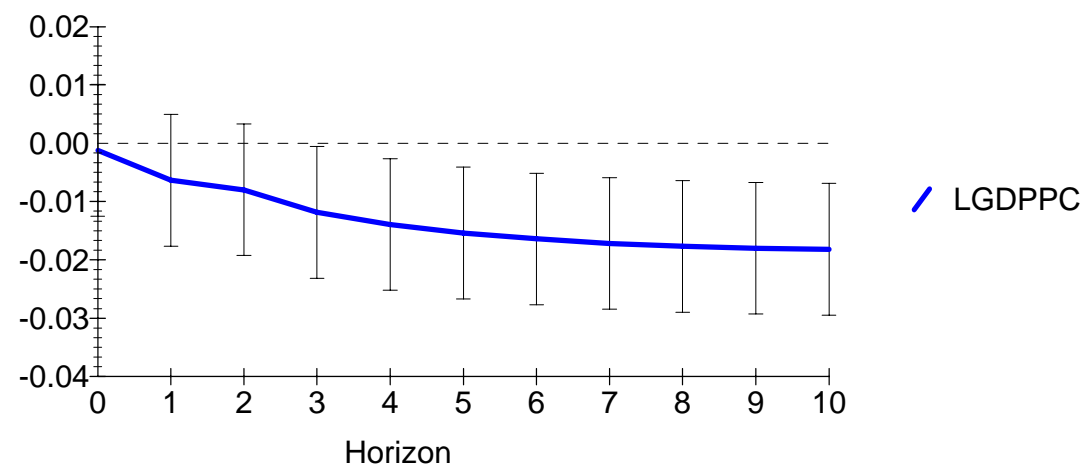

Figure 23

Generalized Impulse Response(s) to one S.E. shock in the equation for LGOVCONP

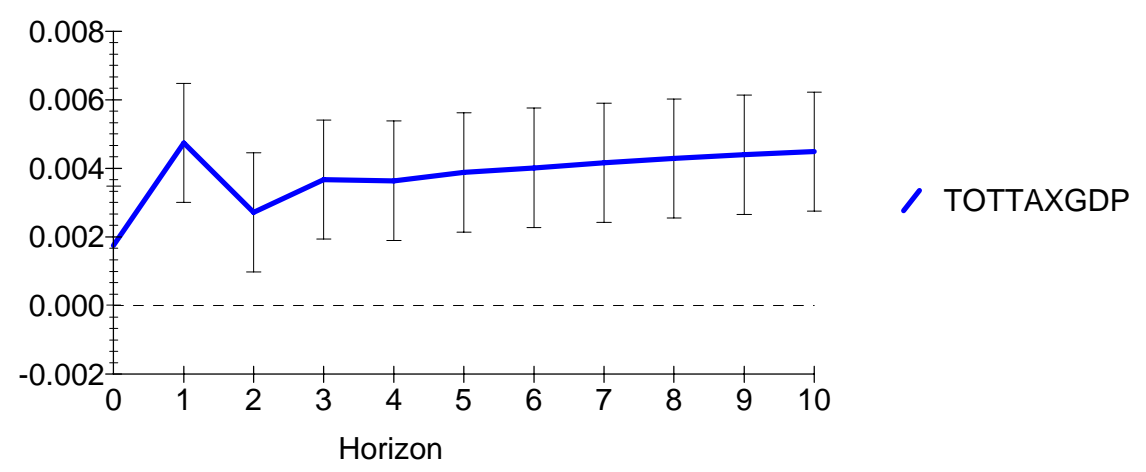

Figure 24

Generalized Impulse Response(s) to one S.E. shock in the equation for LGOVCONP

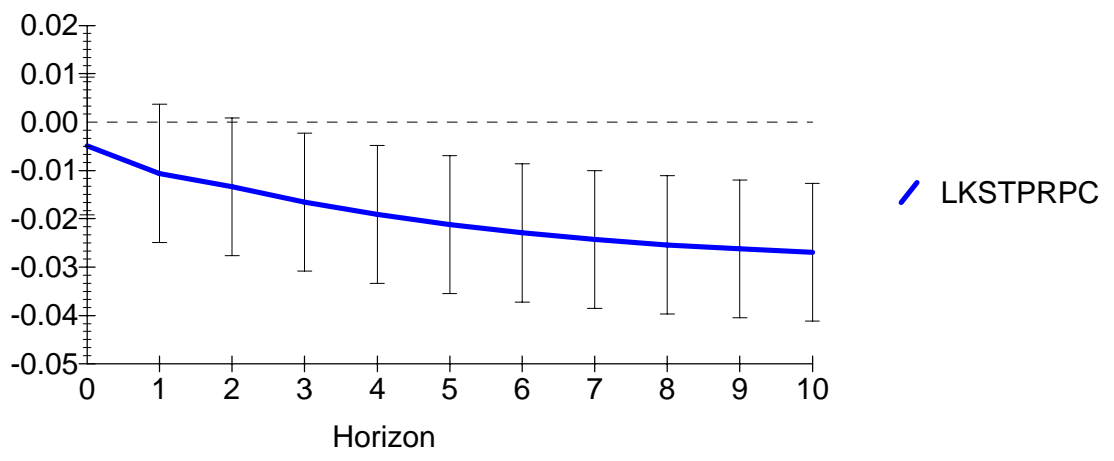


Figure 25

Generalized Impulse Response(s) to one S.E. shock in the equation for LGOVCONP

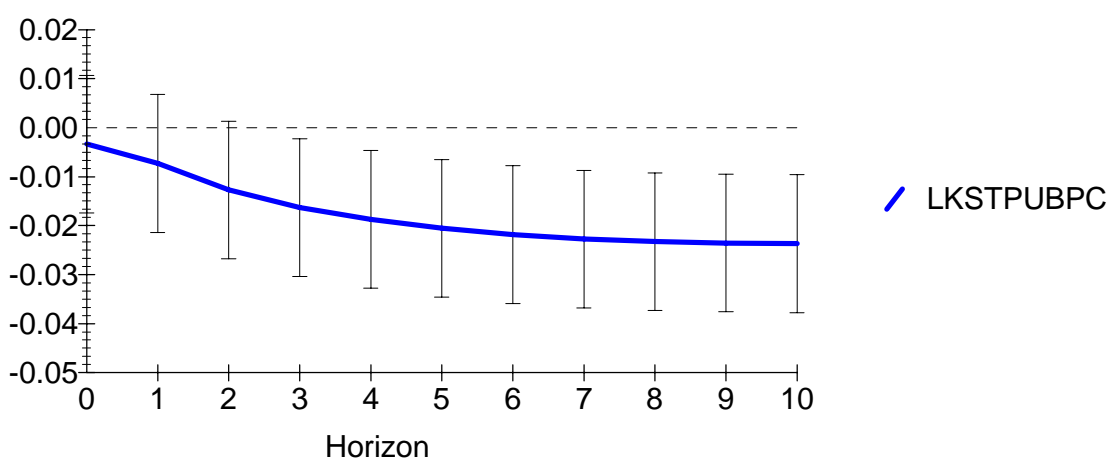

The other two types of government expenditures, namely the subsidies and social security transfers have negligible effects on GDP in the medium term and opposing effects in the long run. Given the small size of this type of expenditure, we will focus here on the effect of social security transfers (see appendix for results of subsidies). Social security transfers have a negative growth effect (Figure 26), primarily because of the associated reduction in the public sector capital (Figure 27). A 5 percent increase in the social security payments is associated with a fall of 3 percent in the public capital stock.

Figure 26

Generalized Impulse Response(s) to one S.E. shock in the equation for LGOVSSTP

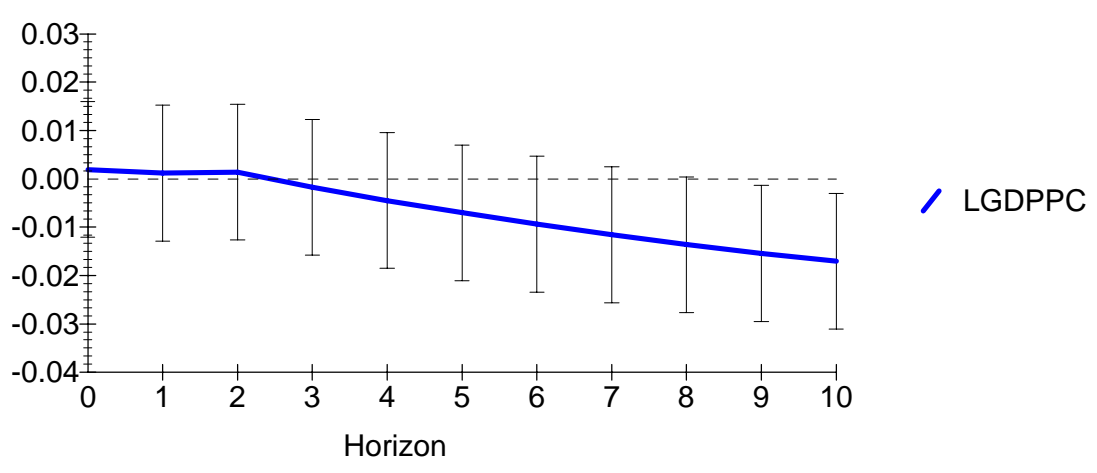


Figure 27

Generalized Impulse Response(s) to one S.E. shock in the equation for LGOVSSTP

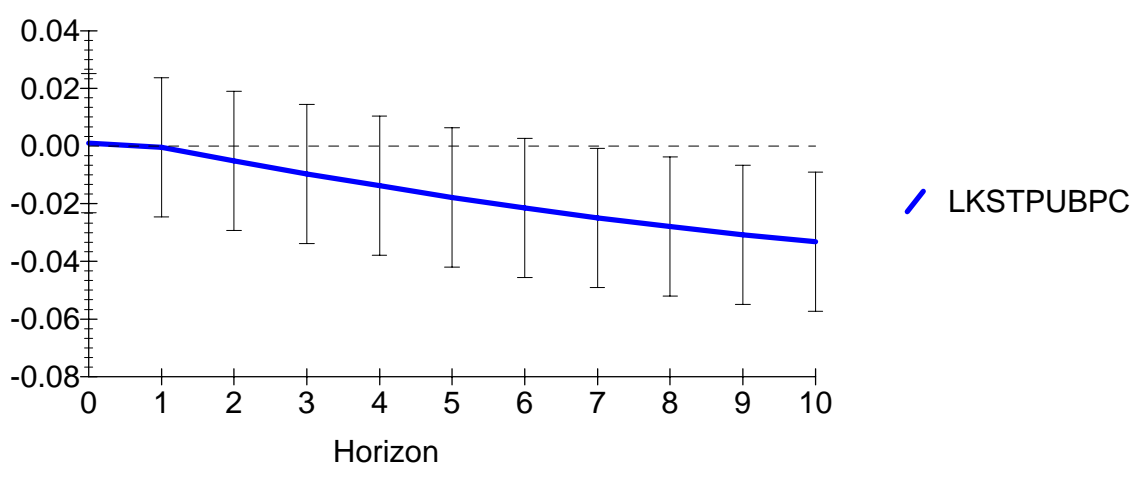

\section{Conclusions and Policy Implications}

During the past decade, the successful episodes of Brazilian stabilization coincide with those when fiscal policy was flexible to increase primary surpluses, while crises emerge when there is little flexibility to adjust this fiscal variable to external shocks. For instance, the 1998-1999 episodes show the importance of the primary balance as a signaling tool in a world of imperfect information. In contrast to the 1998-1999 stabilization, fiscal policy was unresponsive to shocks in 2002, causing concerns of fiscal policy sustainability. Compounded by electoral uncertainty, the situation ended in the 2002 debt crisis

Brazilian fiscal adjustment has been of mixed quality. On one hand, most of the adjustment has been revenue-based and cutting capital expenditures. In the early 1990s, the tax burden was 25\% of GDP while in 2005 it reached 37\%. On the other hand, the expenditure composition shows the rising trend in social security and assistance transfers.

Our findings show that Brazilian fiscal policy is procyclical in the short run: output expansions are associated with smaller primary balances, while output contractions with higher ones. In the long run, however, the evidence shows that fiscal policy is countercyclical, that is a $1 \%$ increase in output is associated with a higher primary balance of $0.2 \%$ of GDP.

The analyses presented in this paper support the contention that Brazil may benefit from increased public spending in the area of economic infrastructure. The econometric analysis using historical data from Brazil indicates positive and strong growth effects of public physical capital stock and public investments. The analysis points out clearly the negative effects of increasing taxation on economic growth. Thus, it is not advisable for Brazil to pursue its need for increasing public investments via expansionary fiscal policy that results in a higher tax burden than the current level. Instead, a long-run solution to recovering an adequate level of public investments must be sought in reallocation of public spending within the fixed overall fiscal envelope. This means the need to re-examine the composition of the current expenditures, including those allocated to the social sectors that today consume a lion's share of Brazil's public expenditures. 


\section{References}

Alesina, A and R. Perotti. 1995. "Fiscal Expansions and Adjustment in OECD Countries.” Economic Policy 21: 207-245.

Aschauer, D. 1989. “Is public expenditure productive?” Journal of Monetary Economics 23:177-200.

Barro, R. 1990. "Government spending in a simple model of endogenous growth." Journal of Political Economy 98(5): 103-125.

Bevilaqua, A.S and R.L.F Werneck. 1998. "Delaying Public-sector reforms: Post stabilization Fiscal Strains in Brazil.” Working Paper Series No 364, Office of the Chief Economist, Inter-American Development Bank.

Belaisch, A. (2003) Excahnge rate pass-through in Brazil. IMF working paper $\mathrm{WP} / 03 / 141$

Blanchard, O. (2003) "Fiscal dominance and inflation targeting; Lessons from Brazil”. Mimeo presented at the World Bank-Casa das Garças Conference in Rio

Candido, José Oswaldo. 2001. “A produtividade dos gastos públicos no Brasil.” Texto de Discussão No 781, Ipea, Brasilia, Brazil.

Cardoso, E. 1998. "Virtual deficits and the Patinkin effect." IMF Staff Papers, Vol. 45, No.3. December

Cashin, P. 1995. “Government spending, taxes and economic growth.” IMF Staff Papers, 42 (2): 237-69.

Drudi, F. and A. Prati. 2000. "Signaling fiscal regime sustainability.” European Economic Review, Vol. 44 pp. 1897-1930.

Eisner,R. 1994. "Real government spending and the future.” Journal of Economic Behavior and Organization, 23, pp 111-126

Favero, C. and F. Giavazzi. 2003. "Inflation targets and debt: Lessons from Brazil.” Mimeo presented at the World Bank-Casa das Garças Conference in Rio

Ferreira, P.C and T. Malliagros. 2003. "Impactos Productivos da Infra-estrutura noBrasil: 1950-1995”.

Gavin, M, R. Hausmann, R. Perotti and E. Talvi. 1996. "Managing fiscal policy in Latin America and the Caribbean: Volatility, Procyclicality and Limited Creditworthiness." IADB. Mimeo, March.

Hurlin, C. 2001a. "Estimating the contribution of public capital with time series production functions: a case of unreliable inference.” Applied Economics Letters 8, pp 99-103.

Hurlin, C. 2001b. “How to estimate the productivity of public capital ?” Mimeo.

IMF. 2002. "Debt Crises. What's different about Latin America?” In: World Economic Outlook 2001: Chapter 2: 61-74.

Kocherlakota, N. and C. Phelan. 1999. "Explaining the fiscal theory of the price level." Quarterly Review. Federal Reserve Bank of Minneapolis. Vol. 23(4). Fall pp. 14-23. 
Ministerio de Planejamiento, Orçamento e Gestão. 2003. "Vinculacoes das receitas dos orcamentos fiscal e da seguridad social e o poder discricionario de alocacao dos recursos do gobernó federal”. Secretaria de Orcamento Federal. Fevereiro.

Muriel, Beatriz. 1999. “Gasto Público e Crescimento Econômico.” MA Dissertation, Economic Department at PUC-RJ, Brazil.

Pesaran, H. and Y. Shin. 1997. "An Autoregressive Distributed Lag Modeling Approach to Cointegration Analysis.” Econometrics and Economic Theory in the $20^{\text {th }}$ Century: The Ranger First Centennial Symposium, Eds. S. Strom and P. Diamond, Cambridge University Press.

Pesaran, H., Y. Shin and R. Smith. 1999. "Bounds testing approaches to the analysis of long-run relationships”. Mimeo

Reis, E, Blanco, F, Morandi, L, Mérida, M e Marcelo de Paiva Abreu. 2002. “O século XX nas Contas Nacionais”. IBGE.

Sturm, J.E. and J. de Haan. 1995.“Is public expenditure really productive?” Economic Modeling, 12, 1 pp 60-72

Talvi, E and C. Vegh. 2000 "Como armar el rompecabezas fiscal?: Nuevos Indicadores de Sostenibilidad”. IADB.

Velloso, R. 2002. "Public Finance in Brazil: Policy Issues and Projections.” Background Paper for World Bank Country Economic Memorandum, Brazil. Washington, D.C.

Woodford, M. 1998. "Public debt and the price level”. Mimeo. Princeton University.

Woodford, M. 2001. "Fiscal requirements for price stability”, Journal of Money Credit and Banking, Vol. 33, No. 3 pp.669-727 
Appendix

\section{Cointegrating Vector Autoregression Tests and Impulse Response Function Analysis}

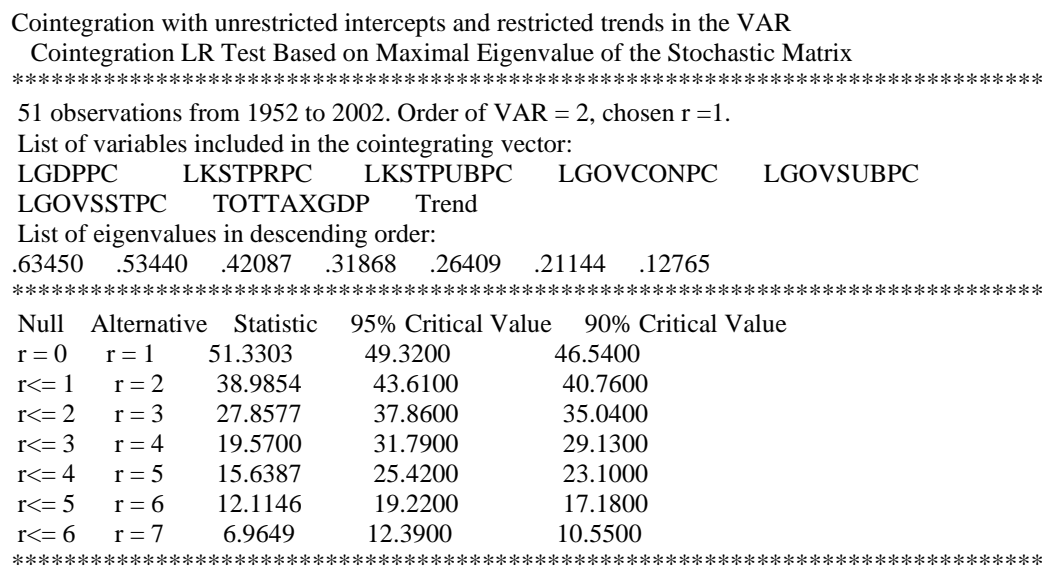

Use the above table to determine $\mathrm{r}$ (the number of cointegrating vectors).

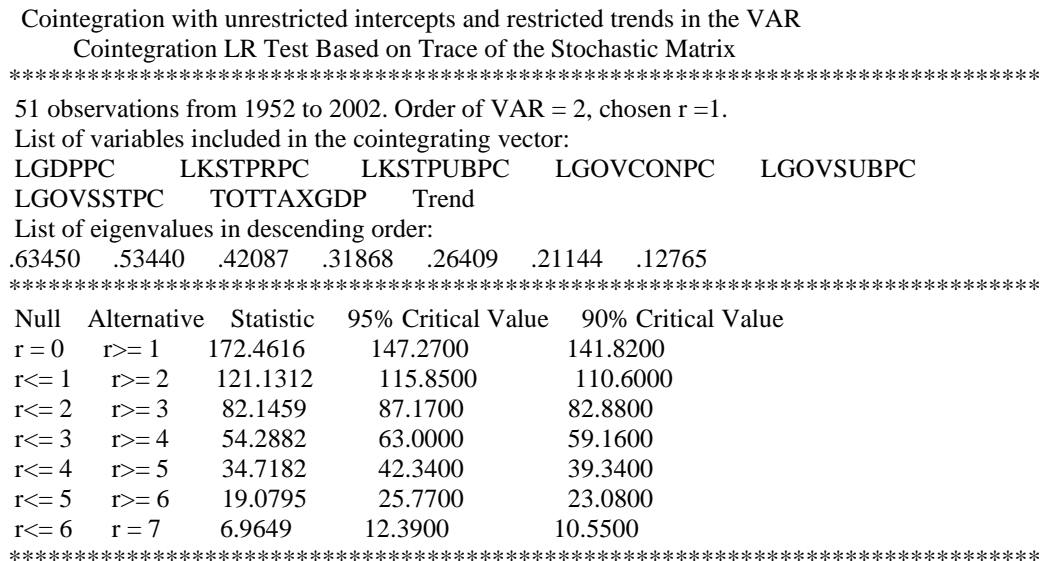

Use the above table to determine $\mathrm{r}$ (the number of cointegrating vectors).

Generalized Impulse Response(s) to one S.E. shock in the equation for LKSTPRPC

Cointegration with unrestricted intercepts and restricted trends in the VAR

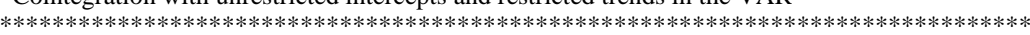

51 observations from 1952 to 2002. Order of VAR $=2$, chosen $r=1$.

List of variables included in the cointegrating vector:

LGDPPC LKSTPRPC LKSTPUBPC LGOVCONPC LGOVSUBPC

LGOVSSTPC TOTTAXGDP Trend

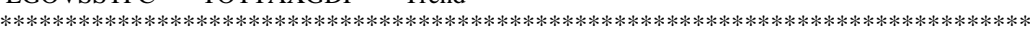

Horizon LGDPPC LKSTPRPC LKSTPUBPC LGOVCONPC LGOVSUBPC LGOVSSTPC

$\begin{array}{ccccccc}0 & .016627 & .014562 & .0081256 & -.027974 & .065454 & -.0021766 \\ 1 & .025658 & .025405 & .017731 & -.022943 & .078764 & .021051 \\ 2 & .032214 & .034483 & .024337 & -.019048 & .12571 & .019772 \\ 3 & .036514 & .042148 & .027711 & -.017208 & .18766 & .012425 \\ 4 & .038430 & .048152 & .029311 & -.017943 & .22577 & .0074402 \\ 5 & .039295 & .052737 & .029744 & -.019157 & .25001 & .0035185 \\ 6 & .039490 & .056160 & .029280 & -.020368 & .26836 & -.4930 \mathrm{E}-3 \\ 7 & .039177 & .058662 & .028179 & -.021643 & .28219 & -.0044187 \\ 8 & .038493 & .060430 & .026667 & -.022958 & .29192 & -.0080820 \\ 9 & .037573 & .061621 & .024921 & -.024256 & .29833 & -.011413 \\ 10 & .036518 & .062364 & .023068 & -.025493 & .30221 & -.014404\end{array}$

Horizon TOTTAXGDP

$0-.0035154$ 
$1-.0032477$

$2-.0037751$

$3-.0048950$

$4-.0056279$

$5-.0063279$

$6-.0069067$

$\begin{array}{lll}7 & -.0074023\end{array}$

$8-.0078145$

$9-.0081562$

$10-.0084361$

Generalized Impulse Response(s) to one S.E. shock in the equation for LKSTPRPC

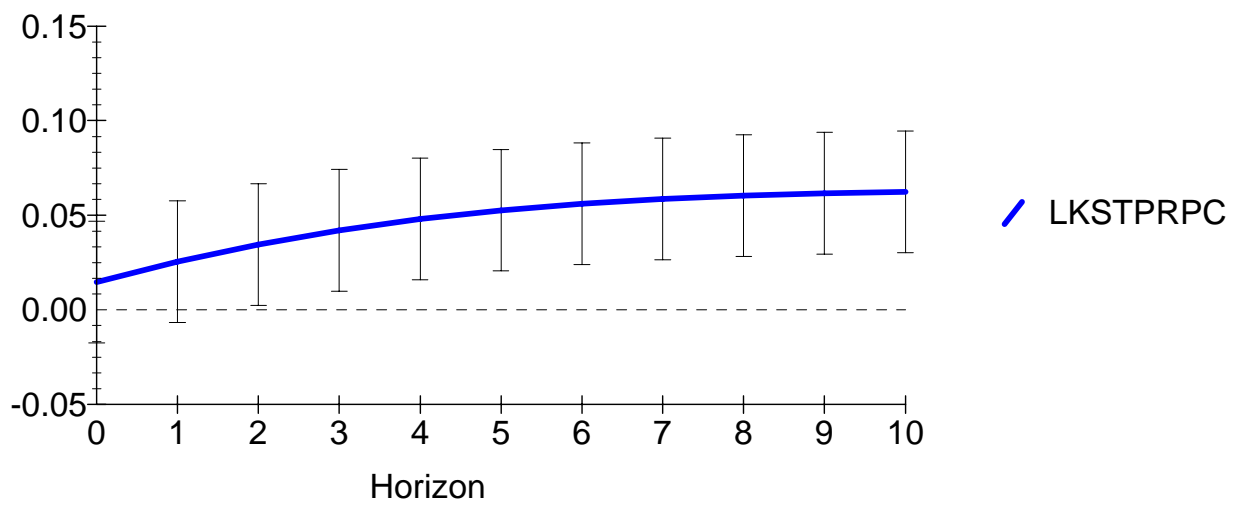

Generalized Impulse Response(s) to one S.E. shock in the equation for LKSTPRPC

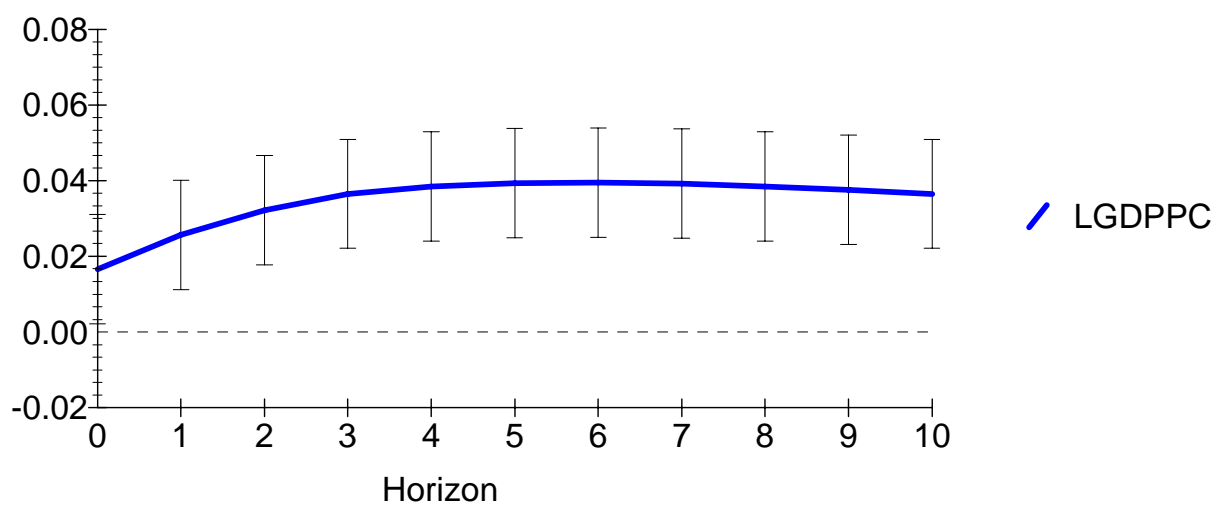



Generalized Impulse Response(s) to one S.E. shock in the equation for
LKSTPRPC

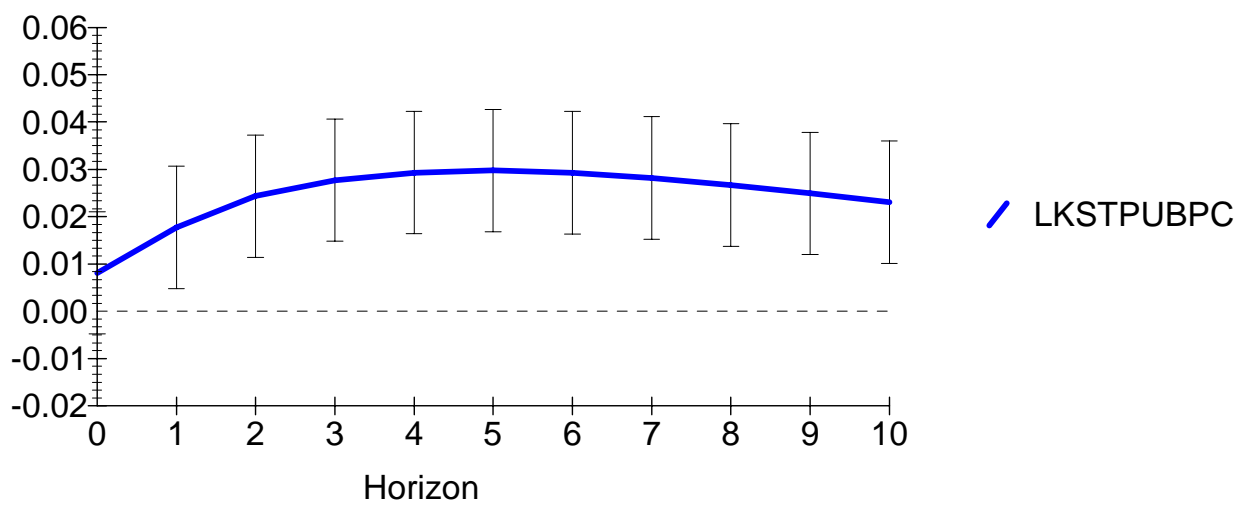

Generalized Impulse Response(s) to one S.E. shock in the equation for LKSTPUBP

Cointegration with unrestricted intercepts and restricted trends in the VAR

51 observations from 1952 to 2002. Order of VAR $=2$, chosen $r=1$.

List of variables included in the cointegrating vector:

LGDPPC LKSTPRPC LKSTPUBPC LGOVCONPC LGOVSUBPC

LGOVSSTPC TOTTAXGDP Trend

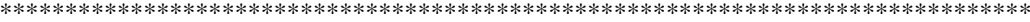

Horizon LGDPPC LKSTPRPC LKSTPUBPC LGOVCONPC LGOVSUBPC LGOVSSTPC

$\begin{array}{ccccccc}0 & .011345 & .0070947 & .016677 & -.016558 & .13219 & .0063188 \\ 1 & .020634 & .015807 & .026809 & -.0067698 & .23730 & -.0060201 \\ 2 & .025799 & .022133 & .036551 & -.0075954 & .25341 & .0045782 \\ 3 & .031537 & .027663 & .044658 & -.0048371 & .27439 & .010285 \\ 4 & .036295 & .032347 & .050987 & -.0022790 & .30233 & .012683 \\ 5 & .040048 & .036364 & .055915 & -.5244 \mathrm{E}-3 & .32659 & .014249 \\ 6 & .042933 & .039740 & .059719 & .6821 \mathrm{E}-3 & .34608 & .015279 \\ 7 & .045161 & .042550 & .062610 & .0015243 & .36203 & .015855 \\ 8 & .046851 & .044866 & .064752 & .0020973 & .37521 & .016022 \\ 9 & .048101 & .046757 & .066294 & .0024504 & .38597 & .015908 \\ 10 & .048999 & .048283 & .067361 & .0026355 & .39464 & .015602\end{array}$

$* * * * * * * * * * * * * * * * * * * * * * * * * * * * * * * * * * * * * * * * * * * * * * * * * * * * * * * * * * * * * * * * * * * * * * * * * * * * * * * *$

Horizon TOTTAXGDP
$0-.0010629$
$1-.0029719$
$2-.0023302$
$3-.0027585$
$4 \quad-.0028822$
$5-.0031124$
$6-.0033051$
$7-.0034995$
$8-.0036784$
$9-.0038433$
$10 \quad-.0039918$ 
Generalized Impulse Response(s) to one S.E. shock in the equation for LKSTPUBP

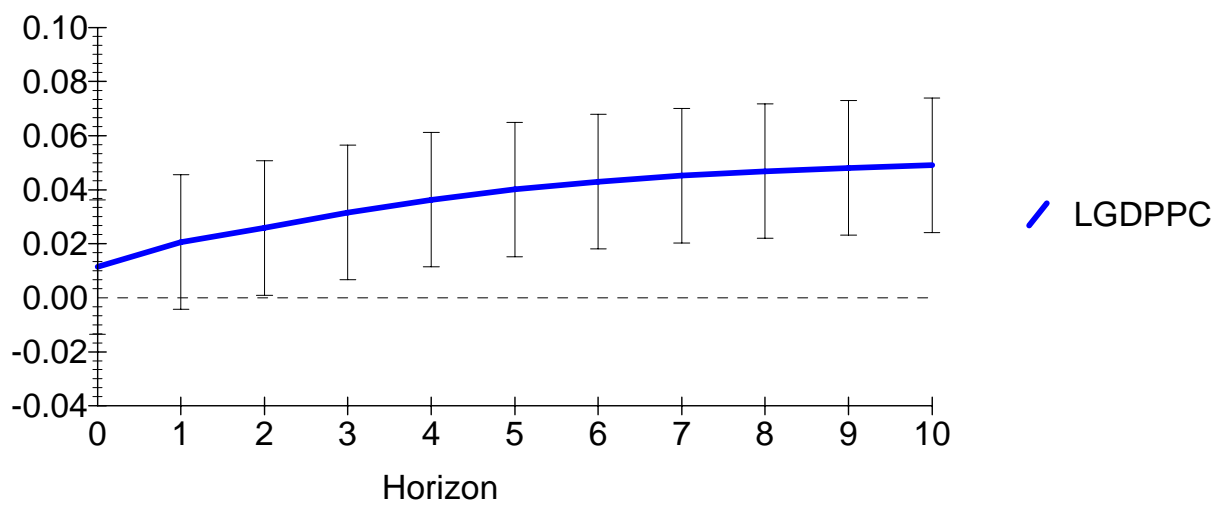

Generalized Impulse Response(s) to one S.E. shock in the equation for LKSTPUBP

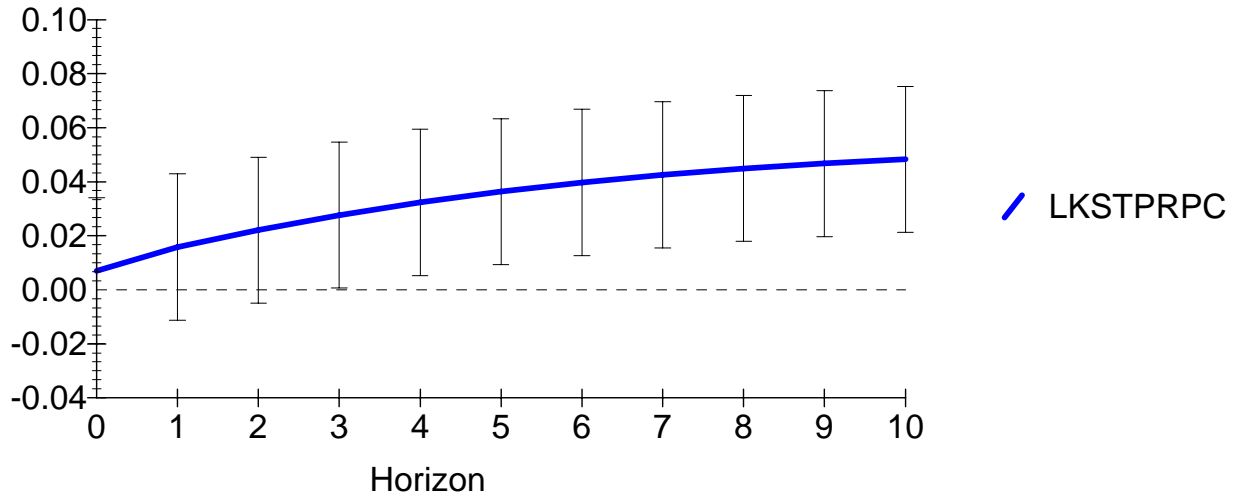

Generalized Impulse Response(s) to one S.E. shock in the equation for LGOVCONP

Cointegration with unrestricted intercepts and restricted trends in the VAR

51 observations from 1952 to 2002. Order of VAR $=2$, chosen $r=1$

List of variables included in the cointegrating vector:

LGDPPC LKSTPRPC LKSTPUBPC LGOVCONPC LGOVSUBPC

LGOVSSTPC TOTTAXGDP Trend

Horizon LGDPPC LKSTPRPC LKSTPUBPC LGOVCONPC LGOVSUBPC LGOVSSTPC

$\begin{array}{ccccccc}0 & -.0012266 & -.0049725 & -.0033710 & .081918 & -.057157 & .015833 \\ 1 & -.0063342 & -.010616 & -.0073041 & .075264 & -.067279 & .0030389 \\ 2 & -.0079829 & -.013413 & -.012694 & .076846 & -.035017 & -.0098600 \\ 3 & -.011856 & -.016518 & -.016313 & .073536 & -.058934 & -.0096376 \\ 4 & -.013946 & -.019063 & -.018720 & .072293 & -.081661 & -.0082162 \\ 5 & -.015388 & -.021208 & -.020534 & .072024 & -.094137 & -.0083018 \\ 6 & -.016416 & -.022924 & -.021836 & .071817 & -.10318 & -.0081722 \\ 7 & -.017176 & -.024302 & -.022719 & .071701 & -.11080 & -.0078422 \\ 8 & -.017687 & -.025394 & -.023268 & .071678 & -.11702 & -.0073495 \\ 9 & -.018002 & -.026250 & -.023566 & .071742 & -.12186 & -.0068164 \\ 10 & -.018170 & -.026908 & -.023678 & .071857 & -.12555 & -.0062669\end{array}$

Horizon TOTTAXGDP

$0 \quad .0017484$

$1 \quad .0047379$

$2 \quad .0027171$

$3 \quad .0036730$

$4 \quad .0036370$

$5 \quad .0038785$

$6 \quad .0040138$

$7 \quad .0041622$

$8 \quad .0042856$ 
Generalized Impulse Response(s) to one S.E. shock in the equation for LGOVCONP

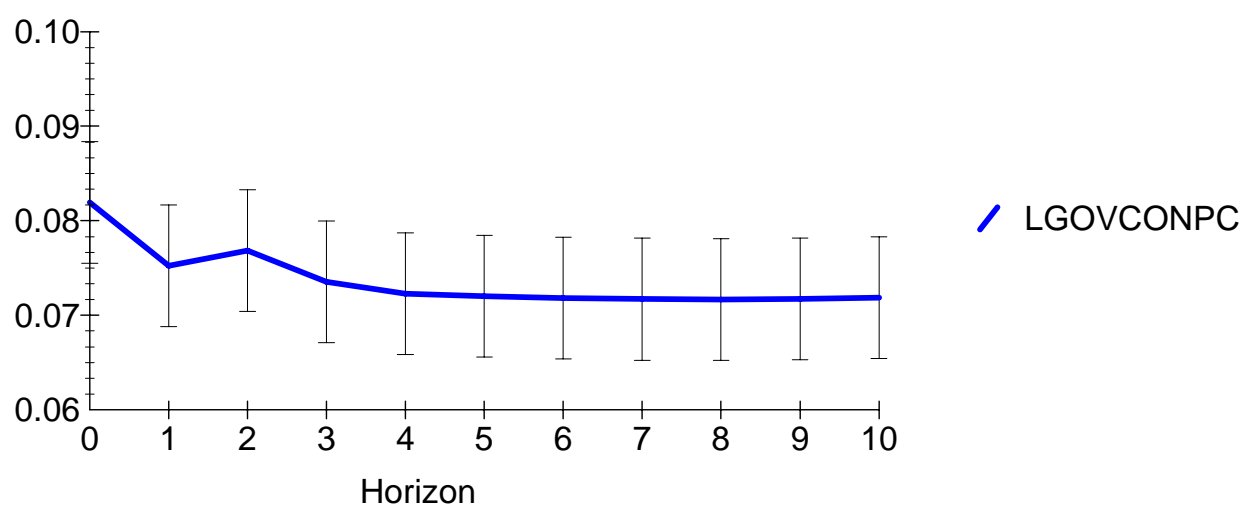

Generalized Impulse Response(s) to one S.E. shock in the equation for LGOVCONP

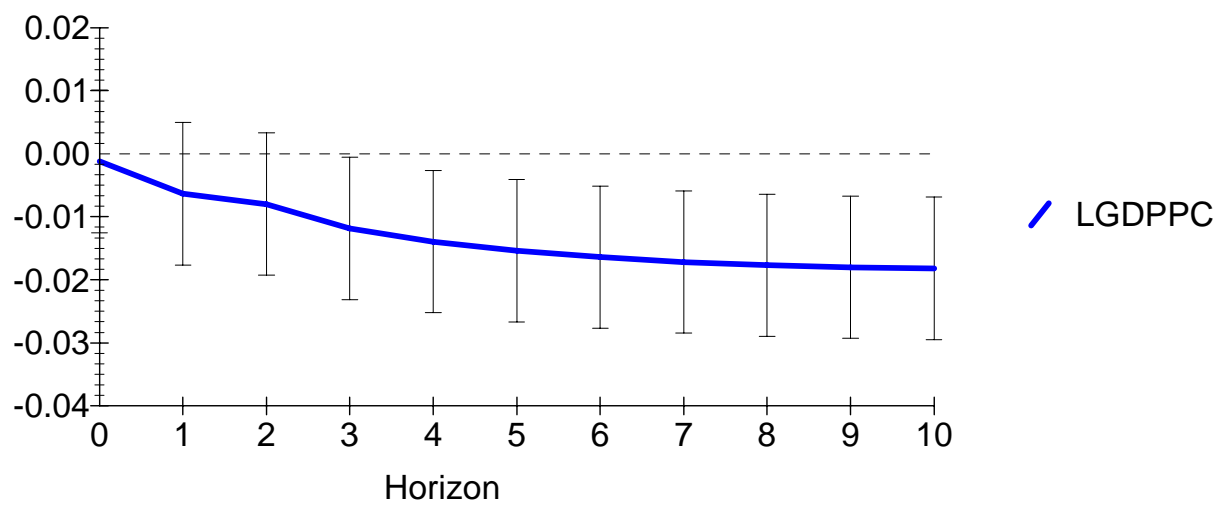

Generalized Impulse Response(s) to one S.E. shock in the equation for LGOVCONP

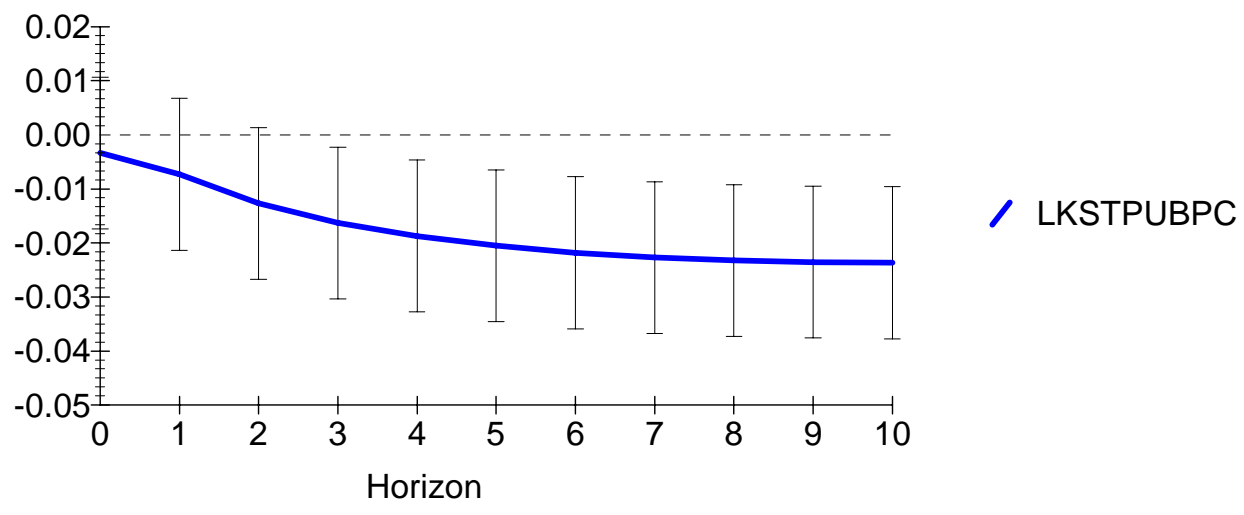


Generalized Impulse Response(s) to one S.E. shock in the equation for LGOVCONP

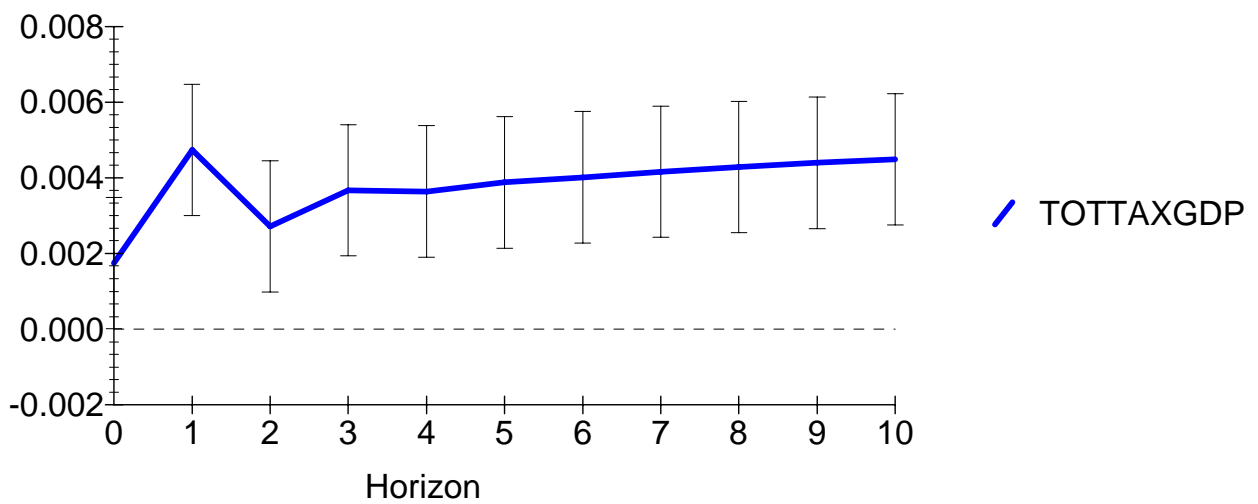

Generalized Impulse Response(s) to one S.E. shock in the equation for LGOVCONP

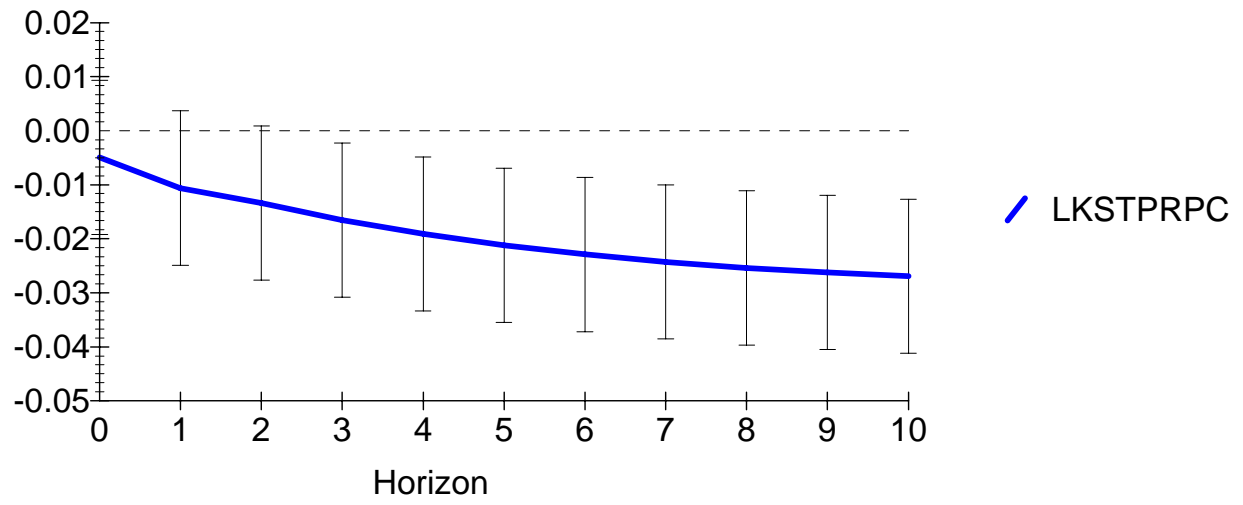

Generalized Impulse Response(s) to one S.E. shock in the equation for LGOVSUBP

Cointegration with unrestricted intercepts and restricted trends in the VAR

51 observations from 1952 to 2002. Order of VAR $=2$, chosen $\mathrm{r}=1$.

List of variables included in the cointegrating vector:

LGDPPC LKSTPRPC LKSTPUBPC LGOVCONPC LGOVSUBPC

LGOVSSTPC TOTTAXGDP Trend

Horizon LGDPPC LKSTPRPC LKSTPUBPC LGOVCONPC LGOVSUBPC LGOVSSTPC

$\begin{array}{lllllll}0 & -.1834 \mathrm{E}-3 & .0023221 & .0053709 & -.011407 & .41045 & .0034785\end{array}$

$\begin{array}{lllllll}1 & -.0047233 & .0049580 & .013452 & -.021805 & .02514 & .010230\end{array}$

$\begin{array}{lllllll}2 & -.9571 \mathrm{E}-3 & .0062209 & .022980 & -.022905 & .27741 & .032231\end{array}$

$\begin{array}{lllllll}3 & .0045022 & .0076236 & .031443 & -.017983 & .04732 & .041459\end{array}$

$\begin{array}{lllllll}4 & .0096596 & .0093974 & .038792 & -.013884 & .29225 & .047777\end{array}$

$\begin{array}{llllllll}5 & .014024 & .011326 & .045221 & -.010722 & .30559 & .053166\end{array}$

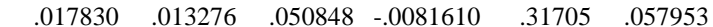

$\begin{array}{llllllll}7 & .021157 & .015171 & .055709 & -.0059682 & .32808 & .061845\end{array}$

$\begin{array}{lllllll}8 & .024033 & .016968 & .059859 & -.0041309 & .063866 & .064958\end{array}$

$\begin{array}{llllllll}9 & .026486 & .018635 & .063367 & -.0026175 & .34846 & .067429\end{array}$

$\begin{array}{lllllll}10 & 028557 & 020154 & 066304 & -.0013854 & .065734 & .069374\end{array}$

Horizon TOTTAXGDP

$\begin{array}{cc}0 & -.7778 E-3 \\ 1 & .3645 E-3 \\ 2 & .3748 E-3 \\ 3 & .0010129 \\ 4 & .0013059 \\ 5 & .0015825 \\ 6 & .0017642 \\ 7 & .0018906 \\ 8 & .0019685\end{array}$ 
Generalized Impulse Response(s) to one S.E. shock in the equation for LGOVSUBP

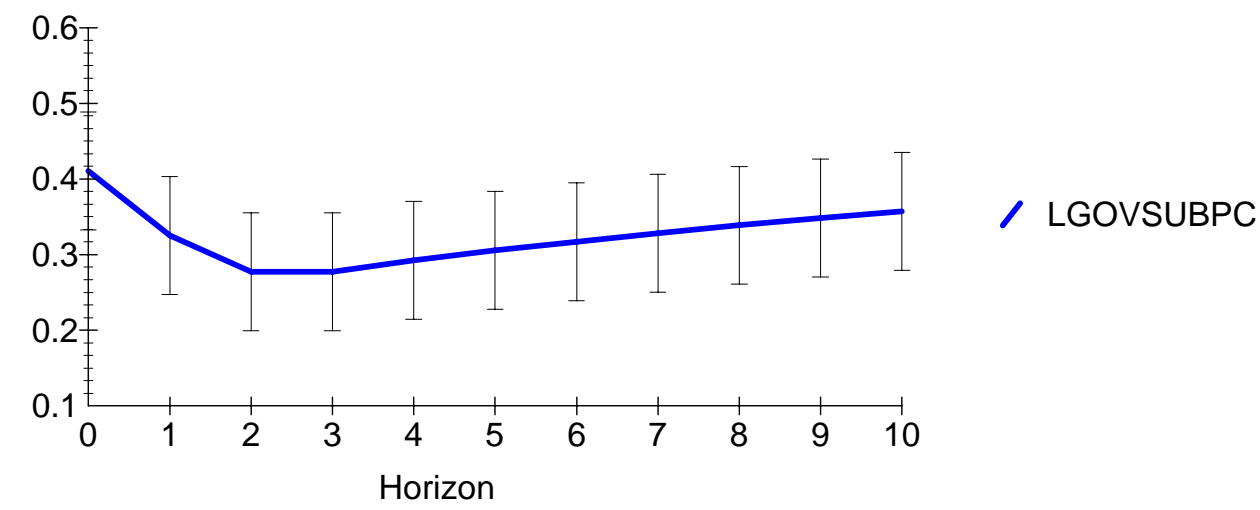

Generalized Impulse Response(s) to one S.E. shock in the equation for LGOVSUBP

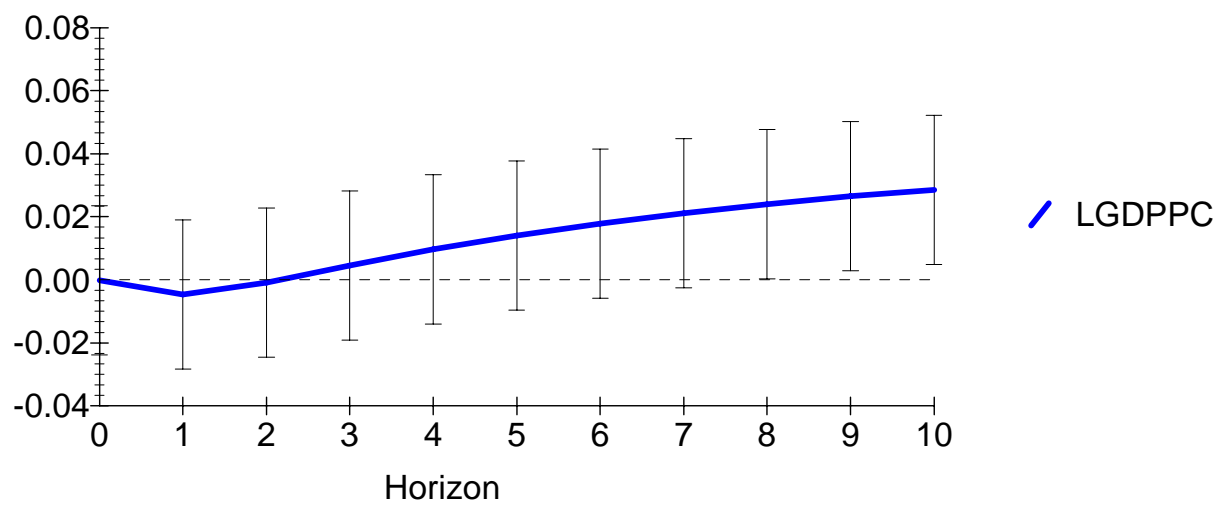

Generalized Impulse Response(s) to one S.E. shock in the equation for LGOVSUBP

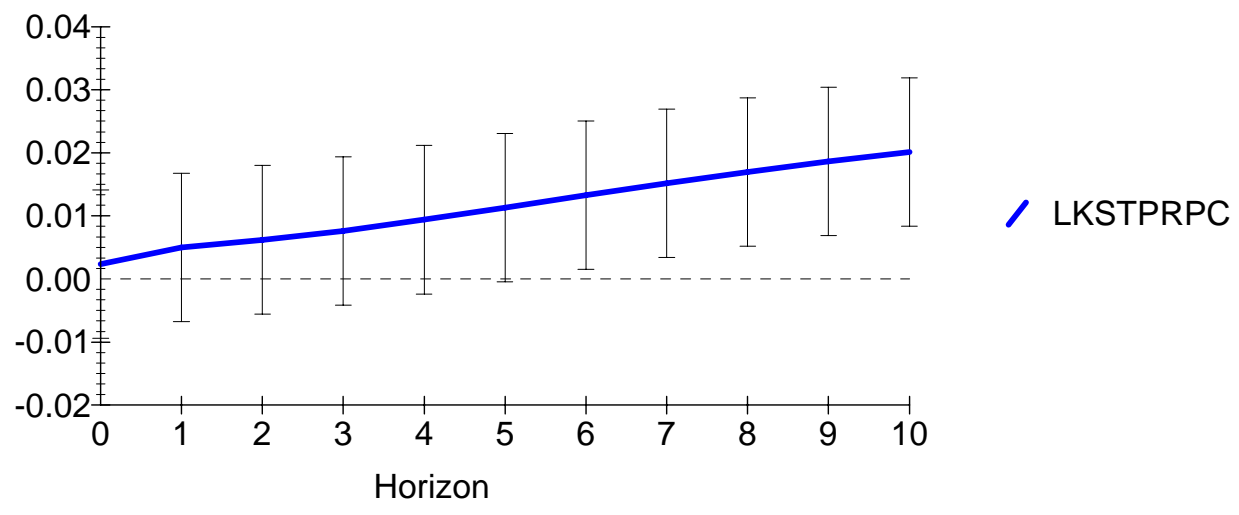




\section{Generalized Impulse Response(s) to one S.E. shock in the equation for LGOVSUBP}

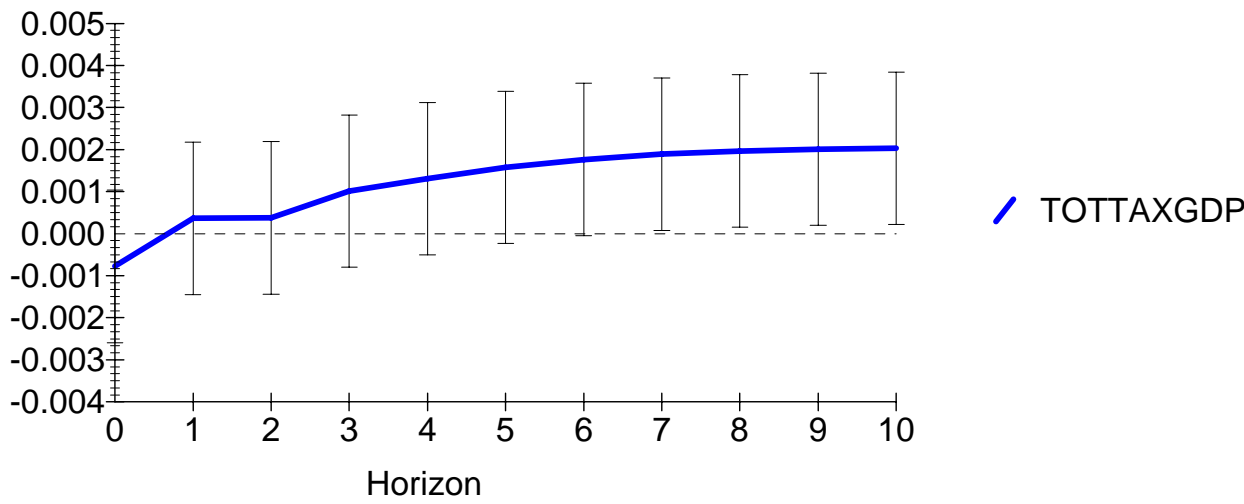

Generalized Impulse Response(s) to one S.E. shock in the equation for LGOVSSTP

Cointegration with unrestricted intercepts and restricted trends in the VAR

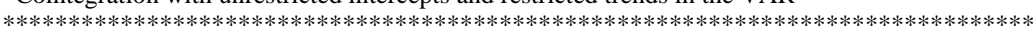

51 observations from 1952 to 2002. Order of VAR $=2$, chosen $r=1$.

List of variables included in the cointegrating vector:

LGDPPC LKSTPRPC LKSTPUBPC LGOVCONPC LGOVSUBPC

LGOVSSTPC TOTTAXGDP Trend

*****************************************************************************************

Horizon LGDPPC LKSTPRPC LKSTPUBPC LGOVCONPC LGOVSUBPC LGOVSSTPC

$\begin{array}{lllllll}0 & .0019381 & -.2959 \mathrm{E}-3 & .9837 \mathrm{E}-3 & .012107 & .013328 & .10713\end{array}$

$\begin{array}{lllllll}1 & .0011795 & .0019477 & -.4699 \mathrm{E}-3 & .016922 & -.010570 & .089721\end{array}$

$\begin{array}{lllllll}2 & .0013863 & .0043558 & -.0050918 & .017783 & .058960 & .072903\end{array}$

$\begin{array}{llllllll}3 & -.0017314 & .0056782 & -.0096745 & .014180 & .071031 & .065039\end{array}$

$\begin{array}{llllllll}4 & -.0045051 & .0062943 & -.013813 & .010979 & .067746 & .060818\end{array}$

$\begin{array}{lllllll}5 & -.0070145 & .0063708 & -.017774 & .0087731 & .066225 & .056110\end{array}$

$\begin{array}{llllllll}6 & -.0093581 & .0061167 & -.021497 & .0068146 & .064668 & .051854\end{array}$

$\begin{array}{lllllll}7 & -.011573 & .0056307 & -.024917 & .0050500 & .061720 & .048211\end{array}$

$\begin{array}{llllllll}8 & -.013606 & .0049960 & -.027999 & .0034921 & .057748 & .045181\end{array}$

$\begin{array}{llllllll}9 & -.015435 & .0042769 & -.030739 & .0021527 & .053336 & .042646\end{array}$

$\begin{array}{lllllll}10 & -.017060 & .0035230 & -.033146 & .0010106 & .048797 & .040543\end{array}$

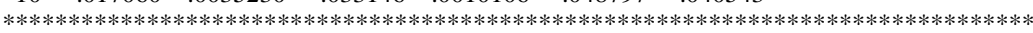

Horizon TOTTAXGDP
$0 \quad .0054594$
1.0062042
2.0042056
3.0040477
4.0034820
$5 \quad .0031519$
$6 \quad .0028533$
$7 \quad .0026343$
$8 \quad .0024645$
$9 \quad .0023388$

$10 \quad .0022474$ 
Generalized Impulse Response(s) to one S.E. shock in the equation for LGOVSSTP

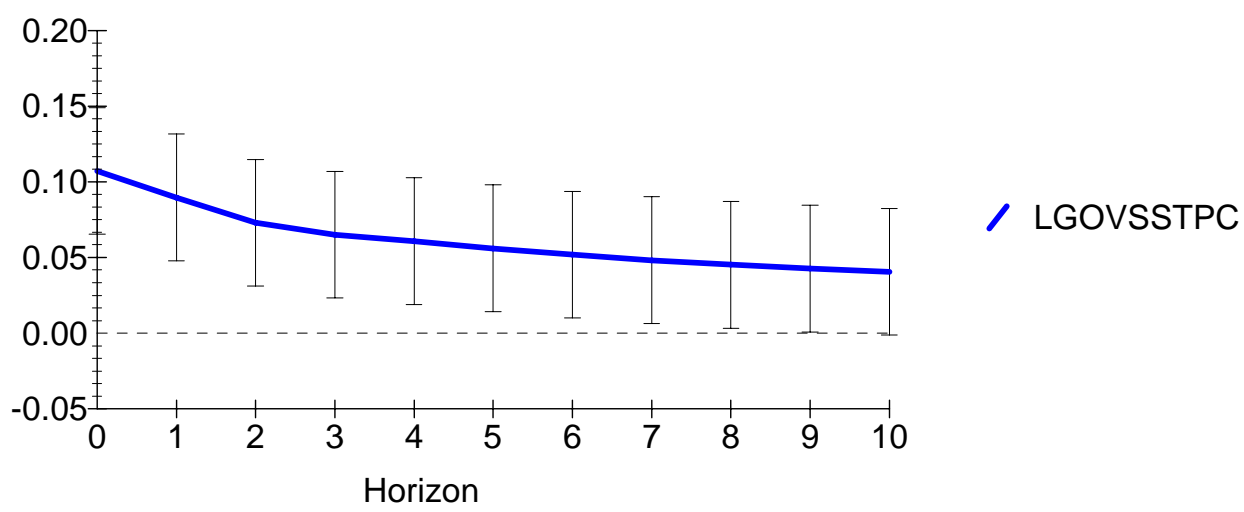

Generalized Impulse Response(s) to one S.E. shock in the equation for LGOVSSTP

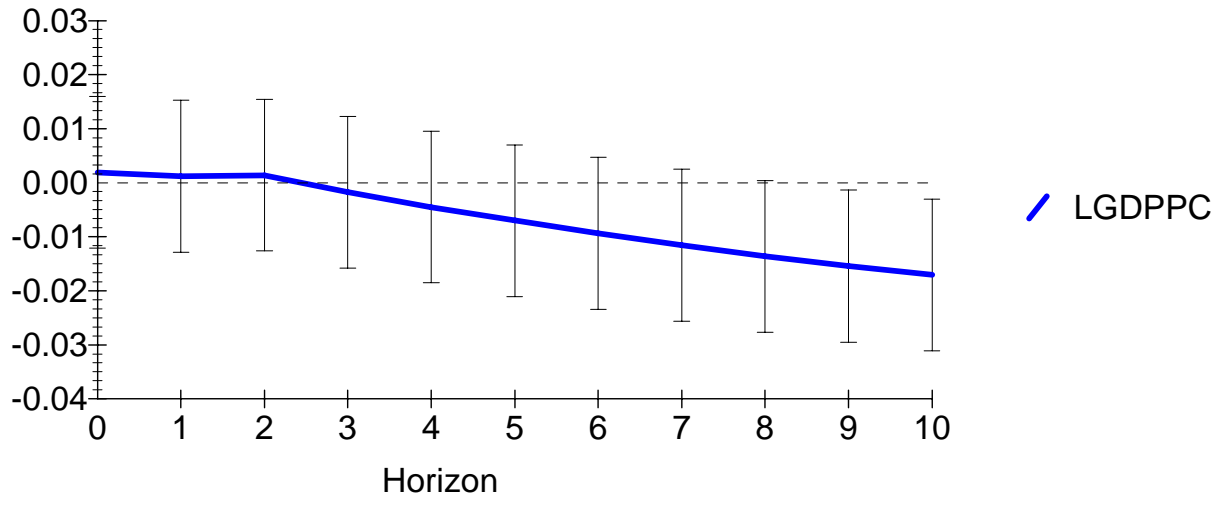

Generalized Impulse Response(s) to one S.E. shock in the equation for LGOVSSTP

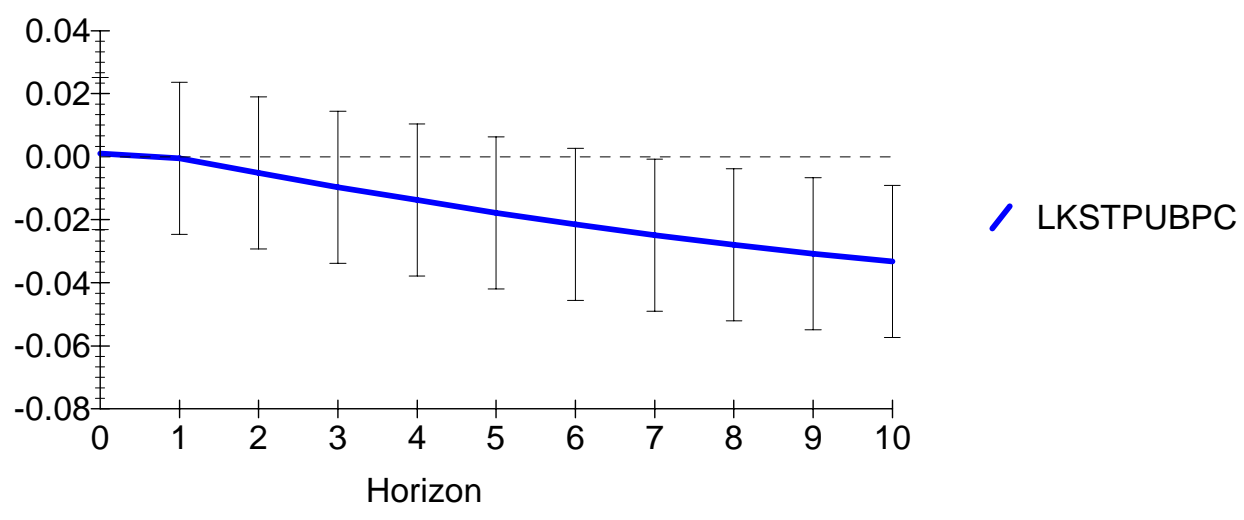


Generalized Impulse Response(s) to one S.E. shock in the equation for LGOVSSTP

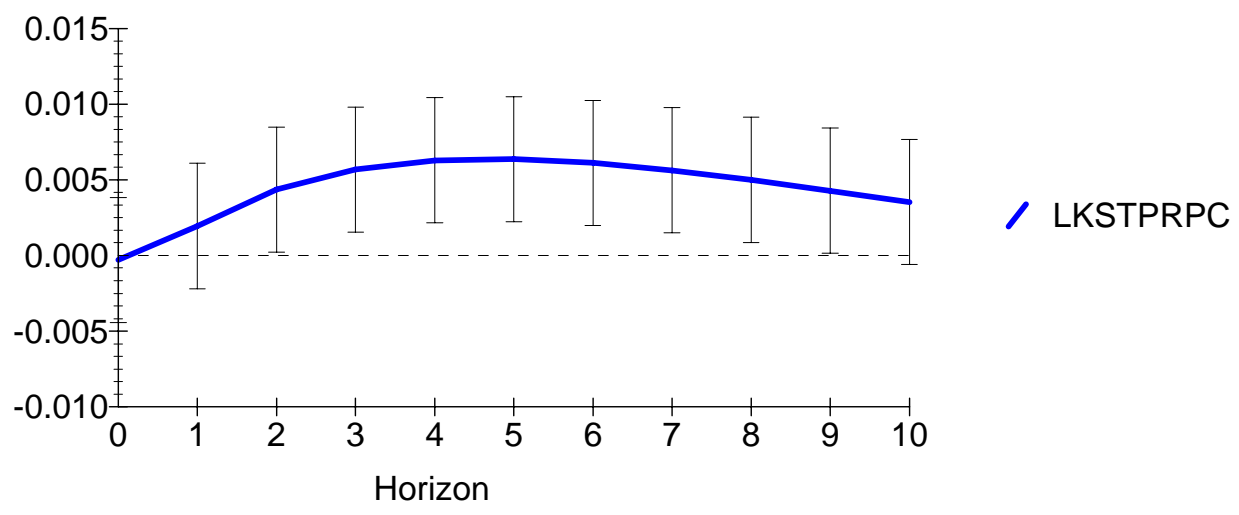

Generalized Impulse Response(s) to one S.E. shock in the equation for LGOVSSTP

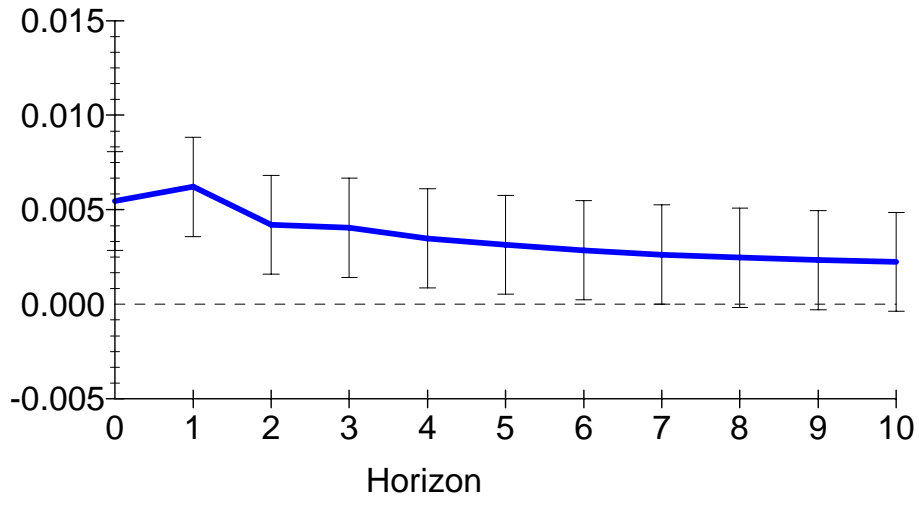

TOTTAXGDP

Generalized Impulse Response(s) to one S.E. shock in the equation for TOTTAXGD

Cointegration with unrestricted intercepts and restricted trends in the VAR

$* * * * * * * * * * * * * * * * * * * * * * * * * * * * * * * * * * * * * * * * * * * * * * * * * * * * * * * * * * * * * * * * * * * * * * * * * * * * * * * * *$

51 observations from 1952 to 2002. Order of VAR = 2, chosen $\mathrm{r}=1$.

List of variables included in the cointegrating vector:

LGDPPC LKSTPRPC LKSTPUBPC LGOVCONPC LGOVSUBPC

LGOVSSTPC TOTTAXGDP Trend

$* * * * * * * * * * * * * * * * * * * * * * * * * * * * * * * * * * * * * * * * * * * * * * * * * * * * * * * * * * * * * * * * * * * * * * * * * * * * * * * * * *$

Horizon LGDPPC LKSTPRPC LKSTPUBPC LGOVCONPC LGOVSUBPC LGOVSSTPC

$\begin{array}{llllllll}0 & -.010611 & -.0028704 & -.9940 \mathrm{E}-3 & .0080314 & -.017900 & .032794\end{array}$

$\begin{array}{llllllll}1 & -.0096439 & -.0023036 & .0015858 & .0039954 & -.091739 & .048012\end{array}$

$\begin{array}{lllllll}2 & -.0084657 & -.0020037 & .0014558 & .0081783 & -.062058 & .039635\end{array}$

$\begin{array}{llllllll}3 & -.0083608 & -.0016234 & .0013504 & .0076156 & -.053646 & .038901\end{array}$

$\begin{array}{llllllll}4 & -.0085176 & -.0013751 & .0012866 & .0073070 & -.054116 & .038778\end{array}$

$\begin{array}{llllllll}5 & -.0085598 & -.0012086 & .0012259 & .0071459 & -.054266 & .038759\end{array}$

$\begin{array}{llllllll}6 & -.0085979 & -.0010924 & .0011232 & .0070904 & -.053591 & .038484\end{array}$

$\begin{array}{llllllll}7 & -.0086577 & -.0010126 & .0010006 & .0070081 & -.053045 & .038237\end{array}$

$\begin{array}{lllllll}8 & -.0087319 & -.9630 \mathrm{E}-3 & .8713 \mathrm{E}-3 & .0069219 & -.052770 & .038028\end{array}$

$\begin{array}{lllllll}9 & -.0088097 & -.9367 \mathrm{E}-3 & .7422 \mathrm{E}-3 & .0068412 & -.052651 & .037848\end{array}$

$\begin{array}{lllllll}10 & -.0088870 & -.9276 \mathrm{E}-3 & .6171 \mathrm{E}-3 & .0067688 & -.052621 & .037689\end{array}$

Horizon TOTTAXGDP

$\begin{array}{cc}0 & .017834 \\ 1 & .014326 \\ 2 & .014827 \\ 3 & .014616 \\ 4 & .014628\end{array}$ 
Generalized Impulse Response(s) to one S.E. shock in the equation for TOTTAXGD

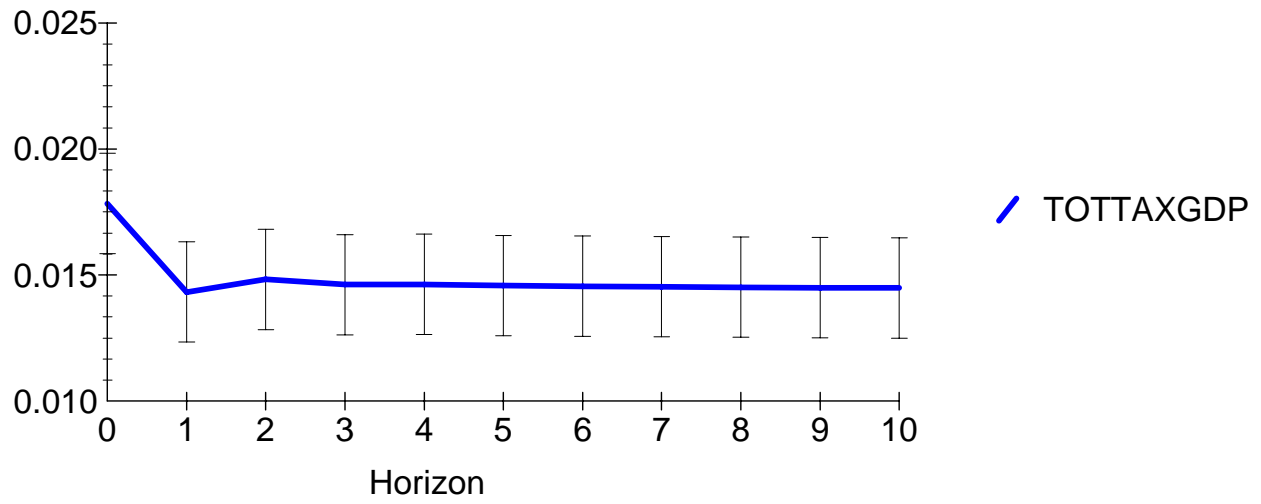

Generalized Impulse Response(s) to one S.E. shock in the equation for TOTTAXGD

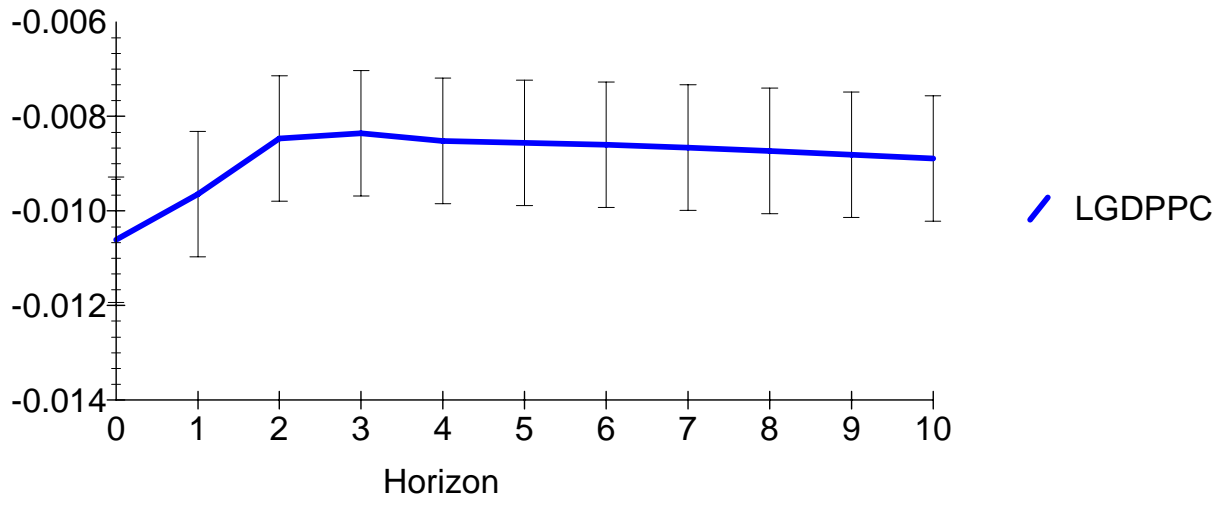

Generalized Impulse Response(s) to one S.E. shock in the equation for TOTTAXGD

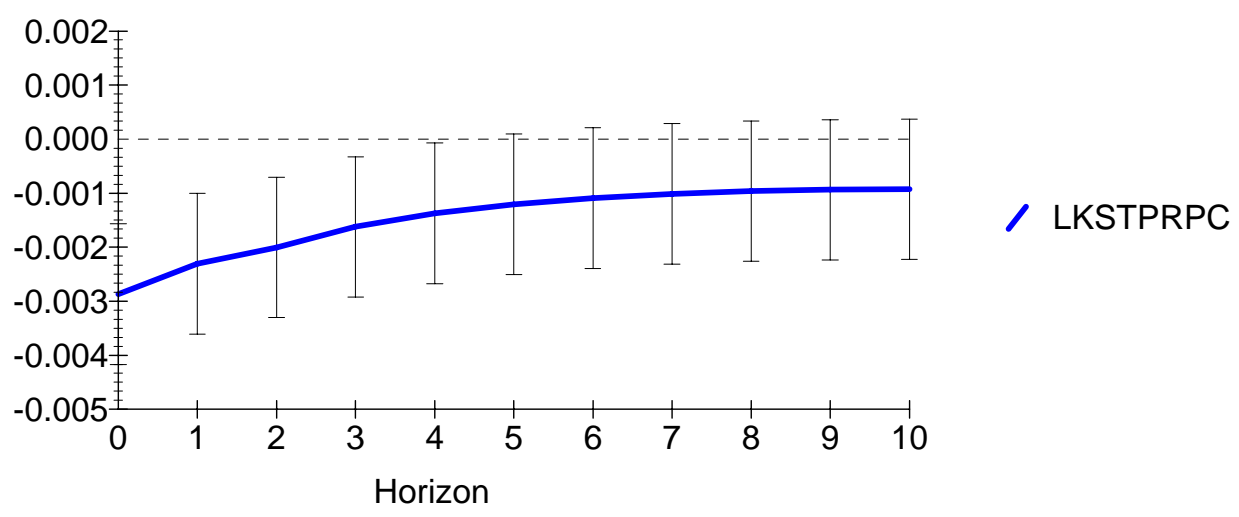


Generalized Impulse Response(s) to one S.E. shock in the equation for TOTTAXGD

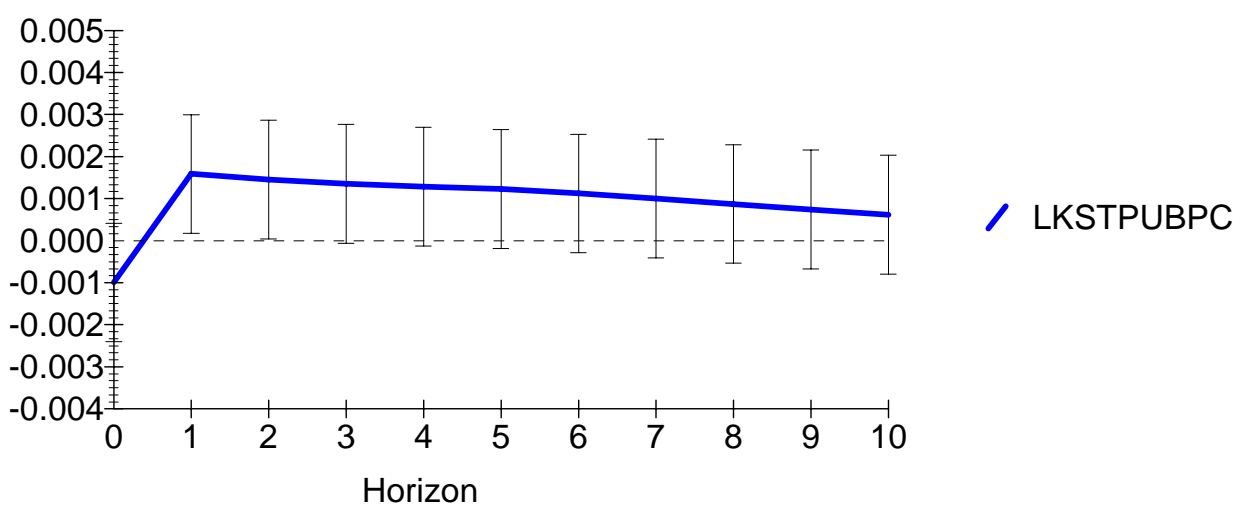

wb176149

L:Ibrazil\QualityFiscaPolicyin Brazil_revised June04.doc

June 16, 2004 12:22 PM 